\title{
Basic Properties of Anthocyanin for Pain Management
}

\author{
I. Putu Eka Widyadharma ${ }^{1,2 *}$, Andreas Soejitno ${ }^{2}$, Made Jawi $^{1,3}$, Thomas Eko Purwata ${ }^{1,2}$, Dewa Ngurah Suprapta ${ }^{1,4}$, \\ A. A. Raka Sudewi ${ }^{1,2}$
}

${ }^{1}$ Department of Biomedical Sciences, Faculty of Medicine, Udayana University, Bali, Indonesia; ${ }^{2}$ Department of Neurology, Faculty of Medicine, Udayana University, Sanglah General Hospital, Bali, Indonesia; ${ }^{3}$ Department of Pharmacology, Faculty of Medicine, Udayana University, Bali, Indonesia; ${ }^{4}$ Laboratory of Biopesticide, Faculty of Agriculture, Udayana University, Bali, Indonesia

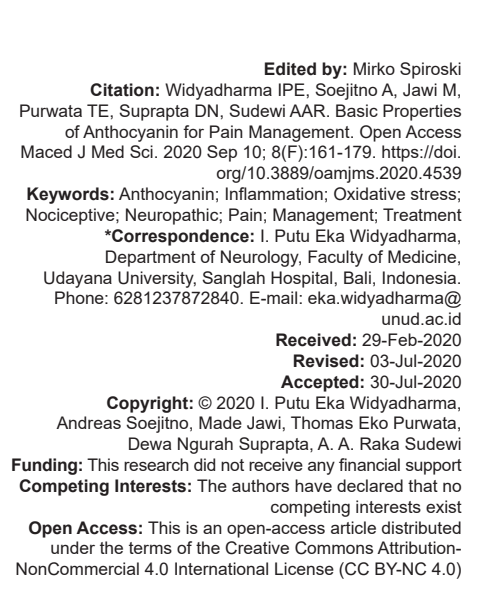

\begin{abstract}
Inflammation and oxidative stress is both two important key players in the development, enhancement, and maintenance of both nociceptive and neuropathic pain. They are almost invariably involved in pain-related diseases, such as all-cause low back pain, diabetic neuropathy, neurodegenerative diseases, myocardial ischemia, cancer, and various autoimmune disorders, among others. They act synergistically and their presence can be beneficial, yet detrimental to neurons and nerves if they are in overdrive state. Meanwhile, anthocyanin, a group of flavonoid polyphenols, is very common in nature and can be easily derived from fruits and vegetables. Accumulating evidence has shown that anthocyanin possesses potent anti-inflammatory and anti-oxidant effects through numerous mechanisms and that its proof-of-concept in ameliorating various pathology of disease states have been extensively documented. Unfortunately, however, the empirical evidence of anthocyanin for alleviating pain has been very minimal to date, despite its potentials. Herein, we discuss the basic properties of anthocyanin and its relevant pain mechanisms which could become potential targets for pain management using this natural compound.
\end{abstract}

\section{Introduction}

Pain is a universal feeling innately presents in almost every human being. Naturally, pain is designed to protect our body from various harmful insults, yet pain can often be problematic during persistent pathological states, such that seen in the majority of diseases. Further complicating matters, abnormal processing of pain signals either in the periphery or in the central nervous system (CNS) in the presence of ongoing noxious insults can lead to the development of neuropathic pain. Neuropathic pain is difficult to manage due to multiple issues, including inadequate diagnosis, high complexity, and less understanding of the mechanisms involved, inappropriate treatment selections and outcome reporting, and inadequate comorbidity management [1]. In fact, the limited options for neuropathic pain have led to the surge of opioid addiction and overdose epidemic in the U.S [2]. Given the account of the extremely common prevalence of pain (i.e., more than one-third of Americans suffer from acute or chronic pain [3]) and the desperate needs for novel pain therapeutic strategies, it is worth to take a look on an abundantly available natural substance with strong anti-inflammatory and anti-oxidant properties such as anthocyanin (ANC). ANC has been studied extensively over the past decades and has been proven to either mitigate or alleviate a vast array of diseases, including infections (e.g., common colds, and urinary tract infections), cardiometabolic and degenerative diseases (e.g., hypertension, and myocardial infarction), and to autoimmune disorders (e.g., ulcerative colitis, and systemic lupus erythematosus) [4], [5], [6]. Extensive studies have proven that ANC exerts a clinically significant effect as an anti-inflammatory and anti-oxidant against those aforementioned diseases. Given its potential protective effects toward inflammation and oxidative stress, ANC, thus, is also potential for the treatment of pain, including nociceptive and neuropathic pain. In fact, ANC has been shown to reduce inflammation-induced pain behavior in animal study with similar efficacy as to NSAID, as well as demonstrating proof-of-concept prevention and treatment for diabetic neuropathy [7], [8]. We, therefore, would like to discuss the relevant aspects of ANC and its potential use to be incorporated in the management of pain. 


\section{ANC's baseline characteristics}

ANC is a group of flavonoid polyphenols regarded as the most abundant water-soluble pigments of plants on earth. ANC is derived from two Greek words which mean red blue [9]. According to its name, ANC gives multiple pigments to many fruits, flowers, and other vegetation's, ranging from red, blue, and orange, to purple [10]. ANCs are naturally found as glycoside and bound to sugar groups, thus are also known as anthocyanidins [11]. There are six types of widely spread and readily available anthocyanidins, which are arguably of importance to human diet, comprises: Cyanidin, delphinidin, petunidin, peonidin, pelargonidin, and malvidin (Figure 1) [9], [10]. In addition, glycosylation is essential to increase anthocyanidin's molecular stability and water-soluble capacity [12].

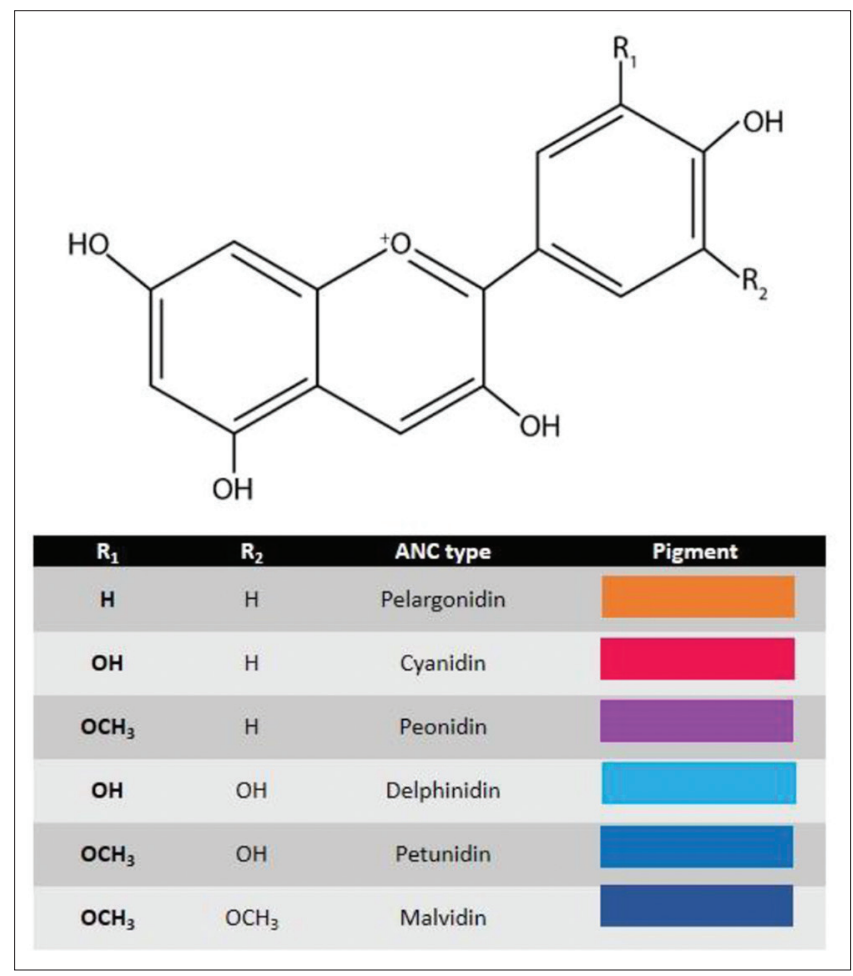

Figure 1: Different types of anthocyanin molecular structure with its associated pigment (adapted from Pojer et al. [9] and Bowen-Forbes et al. [16])

ANC's molecular structure and color are greatly influenced by $\mathrm{pH}$ changes. For instance, it is red to orange in color with eight conjugated double bond-carrying cations under very acidic $\mathrm{pH}$ (i.e., 1-3) [13], [14], it turns into quinodal blue on $\mathrm{pH} 4$ [10], becomes colorless and form a chalcone at $\mathrm{pH}$ 5-6 [9], and ultimately turns to blue-purple with quinodal base at pH 7-8 [15] [16].

ANC has been extensively studied and further processed to become natural food additives [17], as well as food supplements for health-related purposes [18]. In fact, there is plenty of valid evidence supporting the wide-range beneficial effects of ANC in promoting health through various organ systems with numerous molecular mechanisms. For instance, it has been shown through laboratory and epidemiologic studies that ANC consumption can lower the risk of multiple degenerative diseases, ranging from ischemic heart disease to cancer, and helps alleviating generic pain due mainly to its anti-oxidant, anti-inflammatory, and immunomodulation properties.

ANC-rich dietary sources can be easily found in the environment, thanks to its common availability. Among those with highest content are (comprising but not limited to) bilberries (Vaccinium myrtillus) with $405 \mathrm{mg}$ of glucoside-type ANC/100 g, elderberries (Sambucus nigra) with $794.13 \mathrm{mg}$ of glucoside-type ANC and 462.96 sambubioside-type ANC/100 g, chokeberries (Aronia melanocarpa) with $557.67 \mathrm{mg}$ of galactoside-type ANC/100 g, and billberries ( $V$. myrtillus) with $405 \mathrm{mg}$ of galactosidetype ANC/100 g, among others [9], [19], [20]. Given its widespread availability, abundant contents, relative affordability, and well-known health promoting effects, ANC merit further studies and perhaps, to some extent, to be incorporated into the treatment of various diseases of which it has been proven to have protective and/or alleviating effects. In this review, we focus to discuss the pharmacokinetics and pharmacodynamics of ANC, especially for its ability to reduce acute and chronic pain transmission.

\section{ANC's pharmacokinetics (absorption, distribution, metabolism, and excretion)}

ANC has been demonstrated to be rapidly absorbed, that is, it can be detected in the portal and systemic blood plasma within 6-20 min postingestion [21], [22]. Interestingly, it can be absorbed intact, regardless of its molecular sizes and structures or its attached acylated components, although recent evidence seems to confront these findings [23], [24], [25], [26], [27], [28], [29], [30]. The time to reach maximum plasma concentration $\left(T_{\max }\right)$ of ANC varies, depending on the types of active substance, as well as the dietary source of it. In general, based on animal studies, the $T_{\max }$ ranges from $15 \mathrm{~min}$ (as seen in bilberries, and elderberries with cyanidine 3-glucoside), $30 \mathrm{~min}$ (as seen in blackcurrants with cyanidine 3-glucoside and cyanidine 3-rutinoside, and 4-8-week-blueberries), an hour (as seen in dry marrion blackberries with 3-glucoside), and to $2 \mathrm{~h}$ (as seen in delphinidin 3-rutinoside) [9], [24], [23], [31]. It was proposed that the rate and extent of its absorption depend on the structure and composition of glycine, sugar moiety, and its acylation components [31], [32], [33], [34]. It was generally presumed the more complex of an ANC structure, the less rate for it being absorbed [35].

The systemic bioavailability ofANC was reported to be relatively low, with animal studies varied between $0.26 \%$ and $1.8 \%$ [34], [36], [37], [38], [39], [40], [41]. Some data suggested an estimated range of bioavailability between less than 1 and $2 \%$, with only trace amount 
of the substance detected in organs [42]. This finding was supported by the use of radioactive labeling of cyanidin 3-O-glucoside (Cy3G) fed to the mice which showed minimal accumulation of the traced substance outside the gastrointestinal tract tissue (i.e., only $0.76 \%$ of radioactivity was detected), suggesting that Cy3G was poorly absorbed by other organs, despite high accumulation in GI tract (44.5\%) [43]. However, it was suggested that ANC's bioavailability could be much greater when taking into account of the pre-systemic metabolism, such as Phases I and II metabolism, conjugation, microbe-assisted metabolism, as well as enterohepatic recycling [42], [44].

ANC undergoes specific bodily activities which varied between organs it passes. For instance, the exposure of saliva to ANC in the mouth could degrade approximately $50 \%$ of its total amount as a combined result of oral microbes' enzymatic activities, high temperature, and salivary protein bindings [42], [45]. In addition, it also experienced several processes which results in modified ANC structure. For example, oral $\mathrm{pH}$ exposure of 6.78 leads to a significant transformation of native ANC to chalcone (which was reported to be up to $30 \%$ from total ANC content), or its deglycosylation by oral microbes transform it into aglycones [42], [46].

It is suspected that ANC was significantly absorbed in the stomach as opposed to the small intestine. The notion was based on the observation that in situ gastric administration of ANC glucoside and galactoside on rats can readily be observed in the blood plasma in the form of malvidin 3-glucosidase after only 6 min postadministration [21]. ANC absorption in humans has also been confirmed within minutes of its ingestion [47]. In fact, ANC can be found in portal and systemic circulation through translocation activities using bilitranslocase, an organic anion carrier that can be found both in the stomach and liver [21], [48], [49], [50], [51]. Due to the nature of highly acidic gastric content $(\mathrm{pH}$ between 1.5 and 4), ANC is stabilized as well as found in the forms of quinodal as well as the flavylium species which are eligible to be transported to the liver by means of bilitranslocase [9], [42].

ANC can also be absorbed from small intestine through various transport mechanisms. Some of them were sodium-dependent glucose co-transporter-1 or other glucose-associated transporters and intestinal bilitranslocase [42], [49], [52]. It had been reported that ANC absorption was greater in the jejunum (roughly $55 \%$ from total content) followed by duodenum, although to a smaller extent (i.e., 10\%), with no observable absorption through ileum or colon [53]. In total, small intestine was estimated to be responsible for up to $7.5 \%$ absorption of ingested ANC, a 3-7-fold higher than the estimated bioavailability of ANC [9], [54]. The size of the molecule also matters for absorption. ANC, being a large water-soluble molecule, should be transported by means of active diffusion, as opposed to its aglycone version (anthocyanidin) which is known to be hydrophobic, thus can passively diffuse across the enterocytes [9], [55], [56].

In addition to being absorbed in the small intestine, ANC also undergoes metabolism, for example, being hydrolyzed to aglycone by the action of various intestinal enzymes, such as $\beta$-glucosidase, $\beta$-glucuronidase, and $\alpha$-rhamnosidase [9], [57], [58]. The purpose of the transformation is suspected to ease the transport of these molecules. ANC also undergoes methylation by catechol-O-methyl transferase (COMT), an enzyme responsible for the degradation of catecholamines [26], [59], [60]. It occurs in the kidney tubular epithelial cells, as well as in the vascular endothelial cells, after the release of ANCs in the bloodstream [61].

ANC then reaches the liver wherein it undergoes various metabolic processes, including hydroxylation and glucuronidation through Phases I and II metabolisms [28], [33], [42]. However, the extent of ANC metabolism by cytochrome P450 was unknown, but it was assumed to be related to the hydroxylation of nonreactive carbons [42], [62]. Whereas, phase II metabolism consists of conjugation and glucuronidation, with the latter being assisted by Uridine 5'-diphospho - (UDP) glucoronosyl transferase and UDP dehydrogenase enzymes [42], [58], [63].

ANC also undergoes sulfation by phenol sulfotransferase (SULT1) enzyme which can be found in the small intestine, liver, and platelet [38], [64], [65]. The resulting sulfoconjugate formation of ANC (in this case: Cyanidine and pelargonidin) can readily be found in human urine after ingestion of ANC-rich dietary sources [38], [66].

Although ANC absorption was deemed next to none in the large intestine, the organ plays an important role in enterohepatic recycling of bile-containing ANCs [39]. Native ANC can be readily detected in rat's bile after 20 min of its ingestion [22]. It is also interesting to note that bile can undergo a recycling process for more than 20 times, suggesting a prolonged transit time of ANC in the body, along with its potential extended Phase II metabolism [42]. Given the evidence that ANC was found in bile, it is prudent to assume that its excretion was done through urine and feces. Indeed, a human study using blueberry juice demonstrated that only $4 \%$ of native ANC content was found in the urine, with the rest of it was found in the forms of its metabolites [67]. A study using radioisotope-labeled cyanidine 3-glucoside also found that approximately $44 \%$ of ANCs were elimited by means of urine, breath, and feces [68]. The study also found that ANC was degraded into various metabolites, such as phenolic, hippuric, and phenylacetic acids. This is in accordance with another finding in which more than 371 ANC metabolites can be detected in the urine [69].

As mentioned previously, organ uptake of ANC was relatively small. A study using rats fed by 
blackberry (Rubus fruticosus L.) known for its rich ANC content (i.e., $14.8 \mathrm{mmol} / \mathrm{kg}$ diet) compared with those of control diet for 15 days was shown to have highest accumulated ANC in the jejunum $(605 \mathrm{nmol} / \mathrm{g})$, followed by kidney $(3.27 \mathrm{nmol} / \mathrm{g})$, liver $(0.38 \mathrm{nmol} / \mathrm{g})$, and brain (0.25 nmol/g) [22]. A greater amount of ANC accumulation in the kidney was reported by the administration of $500 \mathrm{mg} / \mathrm{kg}$ of cyanidine 3-glucoside, that is, $700 \mathrm{nmol} / \mathrm{g}$, whereas in the prostate gland was found to be roughly $400 \mathrm{nmol} / \mathrm{g}$ [40]. Another study using mice fed with $0.5 \%$ bilberry extracts for 2 weeks demonstrated highest ANC accumulation in the liver by $173 \mathrm{pmol} / \mathrm{g}$ wet weight of tissue [70]. Moreover, this comprises for up to $51.5 \%$ of the total ANC distribution in the body.

\section{Pathophysiology of pain and its relevant targets for ANC}

Pain is defined as an unpleasant sensory and emotional experience that is commonly associated with actual or potential tissue damage [71]. Based on its neurophysiological mechanism, pain can be classified as nociceptive and non-nociceptive. Nociceptive pain is elicited by noxious stimuli (i.e., mechanical, temperature, and chemical) to the peripheral tissue in the body. Whenever the threshold for the stimuli is lowered and/or the magnitude of noxious stimuli increases, sensitization occurs [72], which, in turn, transmits the pain impulse to the dorsal horn of the spinal cord to be further modulated and processed into the thalamus and higher cortical function, respectively [73]. On the other hand, the most relevant non-nociceptive pain is neuropathic pain. Neuropathic pain is defined as ongoing pain after injury to the central or peripheral nervous system (PNS) (including but not limited to trauma, metabolic imbalance, ongoing viral infections, and exposure to chemotherapies) [72]. Neuropathic pain is thought to result from abnormal somatosensory processing in the central and PNS. There are several underlying mechanisms, comprising aberrant activation of transducers and membrane instability (due to biophysical changes of ion channels) induced by the previous nerve injury.

The pathophysiology of pain is very broad and complex; therefore, due to space constraints and relevancy, we focus our discussion on the potential prospects of ANC in pain intervention, especially linked to inflammation and oxidative stress.

\section{Pro-inflammatory cytokines and chemokine}

Inflammation has long been recognized to play key roles in the occurrence and maintenance of various pathological pains [74]. Inflammation may occur following tissue injury by obnoxious stimuli, that is, through mechanical, thermal, or chemical exposure. Inflammation is marked by the production of various cytokines and/or chemoattractant proteins by the peripheral nerves [74], spinal cord [75], the dorsal root ganglion (DRG) [76], cutaneous source [77], resident or recruited macrophages (including astrocytes and microglia) [78], mast cells [79], endothelial cells [80], and Schwann cells [81] (Figure 2). In addition, cytokines can be delivered to the DRG and dorsal horn of spinal cord by means of retrograde axonal or non-axonal mechanisms, thus further extending its coverage [74].

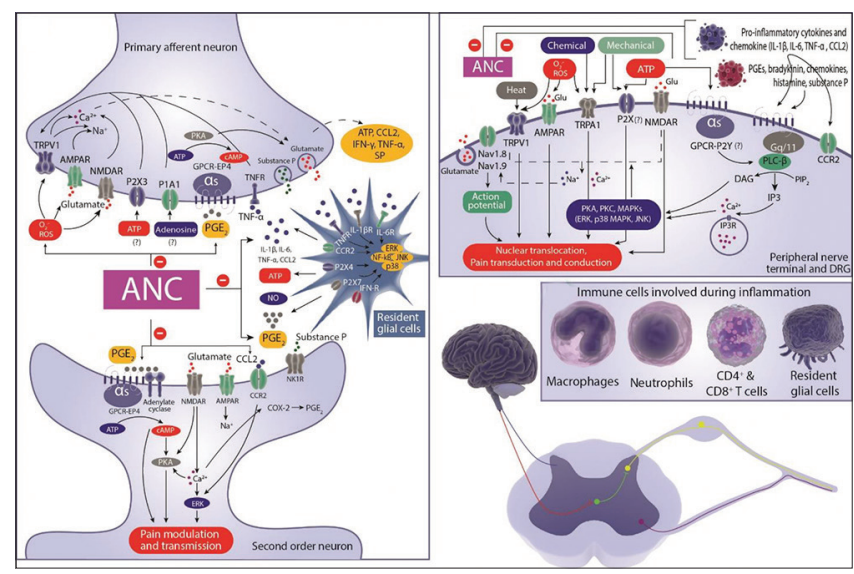

Figure 2: The pathophysiology of neuropathic pain (a) pain is transmitted by means of transduction, conduction, transmission, and modulation, before finally conceived as pain stimulus by brain (perception), (b) various immune cells take roles in these phases, including glial activation in the PNS and central nervous system, (c) various substances and receptors are involved in pain transmission and modulation, including ATP and ROS and its receptors (TRPA1, TRPV1, and purinergic receptors), which were augmented by proinflammatory cytokines during inflammation, all of which could be inhibited by ANC at the level of peripheral nerve and dorsal root ganglion, and (d) second-order neuron (some picture materials were taken and modified from the library of science and medical illustrations by sommersault 18:24, licensed under CC BY-NC-SA 4.0, materials are available under Public License)

Among those cytokines, the most critical group being pro-inflammatory cytokines. There is accumulating evidence demonstrating the involvement of various pro-inflammatory cytokines in the initiation, exacerbation, and maintenance of pathological pain, for example, interleukin $1 \beta$ (IL-1 $\beta$ ). It is commonly synthesized and secreted by the recruited and activated macrophages in the vicinity of inflamed area and even in the DRG neurons [82]. IL-1 $\beta$ has been proven to exert hyperalgesia on in vivo administration [83]. Furthermore, inhibition of IL-1 receptor by an antagonist was able to attenuate hyperalgesia and nerve injuryinduced allodynia [84], [85]. In addition, IL-1 $\beta$ was also responsible to increase certain neuropeptide and lipid compound productions which are strongly associated with pathological pain and inflammation, such as substance $P$ and prostaglandin $E_{2}\left(\mathrm{PGE}_{2}\right)$ [86], [87].

Another example is IL-6. This cytokine has pleiotropic effects with regard to nerves and pain. IL-6 plays an important role in CNS axonal regeneration, but also can be destructive during inflammatory period [88], [89]. IL-6 also activated astrocytes and microglia, two resident glial cells which possess several critical interplays with neurons during either 
physiological or pathological states [90]. Indeed, IL-6 immunoreactivity was observed in the dorsal and ventral horns of rats following nerve injury (e.g., sciatic cryoneurolysis/SCN), whereas its intrathecal administration could mimic and potentiate pain behavior after SCN [91]. In addition, spinal nerve lesion on IL-6 knockout mice demonstrated delayed response of mechanical allodynia [92], suggesting that IL-6 may contribute to the development of neuropathic pain. On the other hand, increased $\mathrm{PGE}_{2}$ levels were shown to increase the secretion of IL-6 from injured nerve, while the administration of selective $\mathrm{PGE}_{2}$ receptor 4 antagonist (EP4) and protein kinase $C$ (PKC) inhibitor attenuated this effect, suggesting that $\mathrm{PGE}_{2}$ may increase IL-6 secretion (or even production) by the recruited macrophages and resident glial cells in an inflamed area by means of PKC pathway and EP4 receptor [93].

IL-6 also plays an important role in cancer pain. An animal study with implanted tumor cell demonstrated an increased level of IL-6 mRNA expression and another study confirmed elevated levels of IL-6 following tumor cell implantation [94]. The mechanism of IL-6-induced cancer pain was thought due to trans-signaling pathway in the DRG, thus inducing its hyperexcitability which in turn upregulates transient receptor potential vanilloid channel type 1 (TRPV1) through Janus-activated kinase (JAK)/Phosphoinositide 3-kinase (PI3K) signaling pathway [95].

Tumor necrosis factor-alpha (TNF- $\alpha$ ) is another critical cytokine in the pathophysiology of inflammatory pain. It was predominantly secreted by microglia under the influence of interferon gamma (IFN- $\gamma$ ) during neuroinflammatory events. Intraplantar injection of TNF- $\alpha$ had been shown to induce mechanical and thermal hyperalgesia. TNF- $\alpha$ bound to TNF receptor 1 (TNFR1) and TNFR2, both of which found in both neurons and glial cells [96], which in turn activated NF-KB following peripheral nerve injury [93]. Furthermore, the administration of TNF- $\alpha$ antagonists was shown to attenuate inflammation in human intervertebral disk cells and hyperalgesia from two independent studies [83], [97]. In addition, TNF- $\alpha$ was thought to play a role in the neuropathic pain by increasing $\mathrm{Ca}^{2+}$ permeable AMPARs insertion in the spinal cord neurons which, in turn, induced mechanical allodynia [98]. It was also shown that TNF- $\alpha$ upregulated IL- 6 expression in the DRG on binding with TNFR1 through nuclear factor kappa-light-chain-enhancer of activated $B$ cells (NF-kB) activation [93]. It is also interesting to note that TNF- $\alpha$ induced Wallerian degeneration on nerve injection, as well as demonstrated the appearance of neuropathic pain behaviors [74].

Besides pro-inflammatory cytokines, chemoattractant cytokines (or also known as chemokines) also play a critical role in the modulation of pain. This is especially true for chemokine (C-C motif) ligand 2 (CCL2) (previously known as monocyte chemoattractant protein 1/MCP-1), a chemokine which acts to recruit and regulate migration and infiltration of monocytes, neutrophils, and glial cells [99]. CCL2 and its receptor (CCR2) are upregulated in peripheral nerve injury as well as other cases, including neuroinflammation, or CNS trauma [74]. CCR2s were identified in DRG neurons and an animal model lacking these receptors was shown to be protective from developing mechanical allodynia, whereas a persistent upregulation of CCR2s in DRG and peripheral nerve was seen following injury [74]. These findings suggest that CCL2 is likely involved in mediating nociceptive and chronic neuropathic pain, as well as present in various other neuroinflammatory conditions. It is also relevant to note that CCL2-CCR2 interaction was shown to induce hypersensitivity in a demyelinating neuropathic pain in a time-dependent manner, suggesting that chronic pain should be staged as different molecular interplays and mechanisms take place over variable timing periods [72].

ANC has been able to suppress the production of multiple aforementioned pro-inflammatory cytokines and chemokines, including IL-1 $\beta$, IL-6, TNF- $\alpha$, and CCL2, as well as inhibit its corresponding receptor (i.e., G-coupled protein receptor/GPCR and CCR2). In addition, ANC was also demonstrated to inhibit ATP production, ameliorate ROS in the event of oxidative stress, and suppress glutamate (Glu) release from inflamed neurons. These multifaceted mechanisms were relevant in the pathophysiology of nociceptive and neuropathic pain, thus explaining its mechanism of action for this pathological event (discussed further in section 2.3.4).

\section{Glial activation in CNS and PNS}

Two types of resident glial cells in the CNS, i.e., microglia and astrocytes are activated by various neuropeptides and neurotransmitters secreted from nearby neurons. Under normal physiological conditions, glial cells are important by acting as a physical support for neurons, improving synaptic transmission efficacy, preserving tissue integrity during nerve injury, facilitating neuronal ionic exchange, and continuously communicating with neurons to modulate neuronal transmission [90]. However, during inflamed states, the corresponding neurons may secrete EEA, PGEs, substance $P(\mathrm{SP}), \mathrm{ATP}$, and nitric oxide (NO), all of which induces glial cell activation. Those activated glial cells in turn are recruited to the injury site by the role of the previously described chemokines (esp. CCL2) and secrete various pro-inflammatory cytokines, including IL-1 $\beta$, IL-6, and TNF- $\alpha$ [74].

In addition to pro-inflammatory cytokines, activated glial cells also increase PGEs production through increased cyclooxygenase (COX) enzymes activity [100]. The resulting PGEs, in turn, promote positive feedback to the dorsal root neurons to increase NO production. Interestingly, activated glial cells 
also release NO under the influence of $\alpha$-amino-3hydroxy-5-methyl-4-isoxazolepropionic acid receptors (AMPARs) and metabotropic glutamate (mGluRs), as well as responsible in the production of ATP [90].

NO has been well-demonstrated to play a role in dorsal horn neurons sensitization during inflammatory tissue damage and primary afferent fiber (PAF) injury by means of cyclic guanosine monophosphate (cGMP) formation and PKG-mediated phosphorylation of specific membrane associated proteins (MAPs) [90]. In addition, NO was reported to increase nociception by transported retrograde into the presynaptic PAF terminals and release glutamate, SP, and calcitonin gene-related peptide (CGRP) via cGMP.

PGEs are also critical in the pathological pain state. Prostaglandin $\mathrm{G} 2$ and $\mathrm{H} 2$ are synthesized from arachidonic acid in which its processes are catalyzed by COX enzymes [101]. In general, COX-2 enzyme is thought to be responsible in generating a large amount of prostaglandin $\mathrm{H} 2$, which, in turn, converted into $\mathrm{PGE}_{2}$ by prostaglandin $\mathrm{E}$ synthase (PGES) and -synthase 2 (PGES2) [102]. In fact, COX-2 existence predominates in the spinal cord, especially in regions receiving nociceptive inputs, such as laminae I, II, and X [90]. PGE ${ }_{2}$ binds to its receptors (EP2, EP3, and EP4) and are coupled to G-protein coupled receptor (GPCR) alpha-s which results in adenylate cyclase stimulation and increased cyclic adenosine monophosphate (cAMP) levels with subsequent protein kinase $A(P K A)$ activation [103]. PGE $_{2}$ signaling is thought to increase peripheral nociceptors responsiveness through capsaicin receptor (TRPV1) and tetrodotoxin-resistant sodium channel SCN10A [104], in which its activations are responsible to increase excitability of peripheral nociceptors and facilitate the propagation of nociceptive impulses along the peripheral nerve.

Increasing evidence has demonstrated the role of p38 mitogen-activated protein kinase (MAPK) activation in the event of nociceptive and neuropathic pain [105], [106], [107]. MAPK plays a crucial role in the generation of pain due to its ability to be activated by several microglial receptors, as well as to regulate many inflammatory mediators important in pain facilitation. For example, p38 MAPK pathway was activated following spinal nerve ligation and the administration of its antagonist was proven to prevent allodynia [108]. In addition, minocycline, which is known for its microglial activity inhibitor, was shown to elicit its action through p38 MAPK pathway with the resulting pain attenuation in various pathological states [109]. In neuropathic pain model, activated microglia by ATP was shown to release brain-derived neurotrophic factor (BDNF), wherein it was involved in the shifting of neuronal anion gradient in the event of neuropathic pain [110].

\section{Purinergic pathways and its relations to pain}

Purinergic pathways have been well-documented to be involved in both nociceptive and neuropathic pain transduction, conduction, and transmission, along with its apparent physiological roles in hollow organs. Purinergic pathways involve purinergic receptors which exist in several different types and are found in peripheral nociceptive sensory neurons in the DRG, trigeminal, nodose, and petrosal ganglia [111], [112].

Purinergic receptor nomenclature is defined by the type of the activating cotransmitters, with P1 and $\mathrm{P} 2$ receptor family being activated by adenosine and ADP/ATP, respectively [113]. The P2 receptor family is further divided into two subtypes, P2X and P2Y, by means of pharmacological classification [114] and the mechanisms of signal transduction [115]. P2X subtypes are those with ligand-gated ion channel receptors, whereas P2Y subtypes are those with G-protein coupled receptors (GPCRs) [113], [115].

Under normal physiological conditions, purinergic pathway is involved in various organ signaling. For instance, distended urinary bladder caused epithelial cells to release ATP which readily bound to the purinergic receptor $\mathrm{P} 2 \mathrm{X}_{3}$ and assisted the normal voiding reflex. Another instance was the involvement of both $\mathrm{P} 1$ and $\mathrm{P} 2$ receptor families in the intestinal peristalsis regulation, as well as its serotonin secretion [116], [117]. Other purinergic signaling was found on uterine cervical dilation during late pregnancy as mediated by ATP release and subsequent interaction with $\mathrm{P} 2 \mathrm{X}_{3}$ receptors, as well as in the lung's vagal sensory fibers which play a role in airway's smooth muscle hyperactivity during asthma and chronic obstructive pulmonary disease [118], [119].

Regarding nociceptive stimuli, it was proposed that the pain transduction involves the sensitization of $\mathrm{P} 2 \mathrm{X}_{3}, \mathrm{P} 2 \mathrm{X}_{2 / 3}, \mathrm{P}_{1} \mathrm{~A}_{2}$, and $\mathrm{P} 2 \mathrm{Y}_{1}$ receptors in the sensory neurons found in the peripheral nociceptive terminals of cutaneous region and other organs by the released adenosine and/or ATP/ADP from sympathetic nerves, mechanoreceptors (i.e., Merkel cell), vascular endothelial cells, and even cancer cells. The binding, in turn, generates nociceptive impulse and conducted to the first order neuron in the dorsal column of spinal cord through DRG, then continue to the thalamus and somatosensory cortex after once again modulated by purinergic receptors $\left(\mathrm{P}_{2} \mathrm{X}_{2}, \mathrm{P} 2 \mathrm{X}_{4}\right.$, and $P 2 X_{6}$ )-ATP interaction. It was also proposed that purinergic receptors upregulation was positively associated with TRPV1, suggesting their functional interaction and subsequent sensitization of nociceptive sensory neurons which underlies the development of mechanical hyperalgesia [113], [120], [121].

In fact, $\mathrm{P}_{2} \mathrm{X}_{3}$ receptors were found to be expressed in the cutaneous sensory nerve fibers and the subsequent binding of ATP and $\alpha, \beta$-methylene ATP can activate the $A \delta$ and $C$ fiber nociceptors [122], [123]. It was proposed that ATP also mediates the upregulation of $\mathrm{P} 2 \mathrm{X}_{2}$ and $\mathrm{P} 2 \mathrm{X}_{3}$ receptors in the DRG during cutaneous inflammation and subsequently contributes to a more effective nociceptive sensitization [113], [124]. In 
addition, purinergic mechanism is also involved even in a disease with autoimmune etiology such as inflammatory bowel disease (IBD), wherein the noxious stimuli arise from the intrinsic immune system. It was found that $\mathrm{P}_{2} \mathrm{X}_{3}$-immunoreactive neurons were significantly higher in myenteric plexus of inflamed colon as opposed to normal control [125]. Interestingly, other types of purinergic receptors $\left(\mathrm{P}_{2} \mathrm{Y}_{6}\right.$ and $\left.\mathrm{P} 2 \mathrm{X}_{7}\right)$ were also found to be strongly expressed and upregulated in the resident CD4+ and CD8+ T cells in the medullary thymus and spleen of IBD cases and subsequent administration of $\mathrm{P}_{2} \mathrm{X}_{7}$ receptor antagonist decreased NF- $\mathrm{KB}$ activation in lamina propria immune cells, as well as downregulation of pro-inflammatory cytokine production in colon tissues and put murine colitis into halt [126], [127]. These findings suggest that purinergic signaling mechanisms are not only limited to the peripheral nociceptive sensory neurons but also activated in various immune cells in the event of inflammation, which almost invariably occurs during nociceptive sensitization. In the heart, $\mathrm{P} 2 \mathrm{X}_{3}$ as well as adenosine $\left(\mathrm{A}_{1}\right.$ and $\left.\mathrm{A}_{2}\right)$ receptors were important in the nociceptive transmission through nodose ganglion afferent neurons during myocardial ischemia [128], [129]. Moreover, the $\mathrm{P}_{2} \mathrm{X}_{7}$ and $\mathrm{P} 2 \mathrm{Y}_{2}$ receptors in the heart were found to be upregulated and downregulated, respectively, in the event of ischemiareperfusion injury, suggesting the harmful role of $\mathrm{P}_{2} \mathrm{X}_{7}$ and protective effect of $\mathrm{P}_{2} \mathrm{Y}_{2}$ purinergic signaling pathway [130]. Purinergic and adenosine receptors $\left(P 2 X_{3}, P 2 X_{2 / 3}, P 2 Y_{2}\right.$, and $A_{1}$ subtype) were also found in the articular joints of the temporomandibular [131], knee [132], [133], and ankle [134], anatomical locations that are often be problematic and associated with combined mechanical and inflammatory nociceptive sensitization.

Purinergic signaling also plays a major role in neuropathic pain. Several receptors including $\mathrm{P}_{2} \mathrm{X}_{4}$, $\mathrm{P}_{2} \mathrm{X}_{7}$, and $\mathrm{P} 2 \mathrm{Y}_{12}$ receptors expressed by the activated microglia have been linked to the development of neuropathic pain. ATP was suspected to play a role through binding with these receptors [135]. One mechanism for neuropathic pain signaling modulated by purinergic receptors is through the synthesis and release of BDNF and disinhibition of pain transmission activity by neurons located in the lamina I [136]. The involvement of BDNF was also confirmed by the attenuation of mechanical hyperalgesia-induced neuropathic pain in the absence of $\mathrm{P}_{2} \mathrm{X}_{4}$ receptors [137]. Interestingly, activated $\mathrm{P}_{2} \mathrm{X}_{4}$ receptors require calcium ion and p38 MAPK pathway for the synthesis and release of BDNF from microglia [138], and that this mechanism also applied to the long-term potentiation (LTP) induction of C-fiber by ATP in the dorsal horn of spinal cord [139].

It is also well noted that $\mathrm{P} 2 \mathrm{X}_{7}$ receptors which are commonly expressed in resident glial cells also contribute to neuropathic pain, particularly through inflammation [140]. ATP dependent-activated P2X receptors were known to upregulate pro-inflammatory cytokines, mainly IL-1 $\beta$ [141], [142], TNF- $\alpha$ [143], and IL-6 [144]. IL-1 $\beta$ and TNF- $\alpha$ productions were increased through p38 MAPK pathway, whereas the underlying mechanism of IL-6 upregulation is still unclear [143], [144]. These findings reiterate the importance of inflammationmediated nociceptive and neuropathic pain and that to successfully manage pathological pain; we shall always take inflammation into account.

\section{The anti-inflammatory properties of} anthocyanin

ANC derived from various dietary sources has been studied extensively, particularly with regard to its anti-inflammatory effects. ANC extracted from red raspberries has been demonstrated to suppress COX-2, IL-1 $\beta$, and IL-6 expression, as well as reducing NO synthesis (through inhibited expression of iNOS) in RAW264.7 macrophages [145]. Its subsequent administration to a mouse model with colitis was shown to ameliorate the associated weight loss and cellular damage. ANC exerts its anti-inflammatory effects through inhibiting NF- $\mathrm{KB}$, p38 MAPK, JNK, and Akt signaling pathways [146], [147], [148], [149]. In addition, ANC is also a strong COX enzyme inhibitor. The COX inhibitory capacity was even comparable to NSAIDs such as ibuprofen or naproxen at certain concentrations [150]. In fact, ANC derived from red sweet cherry water was shown to inhibit COX enzymes by $80-95 \%$ at $250 \mu \mathrm{g} / \mathrm{mL}$ [151]. Furthermore, ANC appears to have an increased tendency toward COX-2 rather than COX-1 inhibition. ANC derived from black soybean seed coats has been shown to inhibit UV-induced COX-2 expression [152]. Similarly, ANC-derived purple sweet potato also reduced the expression of COX-2 and iNOS expression in rats with liver injury [153]. This is perhaps due to the heavy involvement of COX-2 in various pathological states, such as ischemiareperfusion injury [154], intestinal inflammation [155], and tumor [156], [157]. Fortunately, both nociceptive and neuropathic pain also have a strong connection with COX-2 as its mediators [158], [159], [160], thus the ability of ANC to inhibit COX-2 and relieve both types of pain would be greatly appreciated. Predictably, strong COX-2 inhibition results in reduced PGE-2 production and release [152], [161], [162], hence, abridging the inflammation and nociceptive sensitization.

The resulting inhibition of inflammatory pathways by ANC was supposedly demonstrated by reduced pro-inflammatory cytokines production and secretion. Indeed, ANC derived from soybean seed coat was shown to inhibit TNF- $\alpha$ expression through NF-kB-dependent pathway [163], whereas ANCsrich extract from bilberry was shown to reduce mRNA levels of iNOS, TNF- $\alpha, \mathrm{IL}-1 \beta$ and IL- 6 , and reduce protein levels of iNOS, TNF- $\alpha$, and NF-кB [164]. In addition, ANC metabolites also reduced IL-6 and VCAM-1 levels in oxidized LDL challenged vascular endothelial cells [165]. 
It is also worth noted that ANC-rich black elderberry administration to hyperlipidemic mice was shown to reduce CCL2 serum levels [166]. Purified ANC supplementation for 24 weeks could reduce plasma CCL2 levels by approximately 11\% [167]. Similarly, delphinidin 3-sambubioside and delphinidin downregulated MEK1/2-ERK1/2 and NF- $\mathrm{B}$ s signaling pathway and lead to decreased IL-6, TNF- $\alpha$, and MCP-1 (also known as CCL2) levels [168]. Reduction in chemokine levels, thus, can potentially reduce resident glial activation and prevent the exacerbation of inflammatory nociceptive sensitization. Indeed, the combined suppression of pro-inflammatory cytokines and chemokine gene expression, production, and release of strawberries-derived ANC extract has been shown to ameliorate reactive astrogliosis, delay disease onset, and extend survival in mice with amyotrophic lateral sclerosis (ALS) [169]. Moreover, ANC can also block glutamate-induced AMPK activation [170], suggesting that ANC may act indirectly in mitigating excessive neuronal excitations.

The various mechanisms of anti-inflammatory actions elicited by ANC should, therefore, be readily demonstrated on a clinical basis. Indeed, a doubleblind RCT of tart cherry drink administration before long distance running was shown to reduce muscle pain significantly among runners when compared to those who did not consume it [171]. A double-blind randomized controlled trial (RCT) assessing the efficacy of cherry juice to osteoarthritis (OA) patients also demonstrated the same outcome, which is a significant reduction of both pain score and highly specific C-reactive protein (hsCRP) inflammatory marker among treatment group [172]. To be specific, ANC has been demonstrated to attenuate inflammation-induced thermal hyperalgesia, mechanical hyperalgesia, and edema in rat model, with similar efficacy to indomethacin at its highest dose (400 mg/kg BW) [173].

Finally, the direct involvement of ANC on purinergic receptors with regard to pain attenuation has yet to be investigated because purinergic receptors have gained accumulating evidence and important roles in both nociceptive and neuropathic pain, and that its inhibition by ANC seems plausible.

\section{Oxidative stress}

Oxidative stress is a condition wherein there is an imbalance between the amount of free radicals and antioxidants. The imbalance can be in the form of excessive free radicals in the presence of relatively inadequate antioxidants. Under normal physiological states, aerobic metabolism as a consequence of various mitochondrial enzymes produces free radicals in the form of reactive oxygen intermediates and nitrogen species (RNI). These are also produced through ultraviolet, ionizing radiation, and air pollution exposures [174]. In addition to these, the electron transport chain activity in mitochondria also generates reactive oxygen species (ROS) [175]. All of those molecules belong to free radicals. A free radical has a free electron on its external orbit and always attempts to find another electron to stabilize itself. Hence, a free-radical may forcefully take an extra electron from nearby biomolecules [174].

Another example of ROS generation is through the activity of nicotinamide adenine dinucleotide phosphate (NADPH) oxidases, cell membrane enzyme complexes to produce ROS which involves in cellular signaling and tissue homeostasis (Figure 3). The enzymes were expressed in the neurons, astrocytes, and microglia. Under abnormal states (e.g., infections), NADPH oxidases can be highly activated (especially NADPH oxidase 2/NOX2 in the CNS), thus resulting in high levels of ROS which is associated with oxidative stress and neurodegeneration [176].

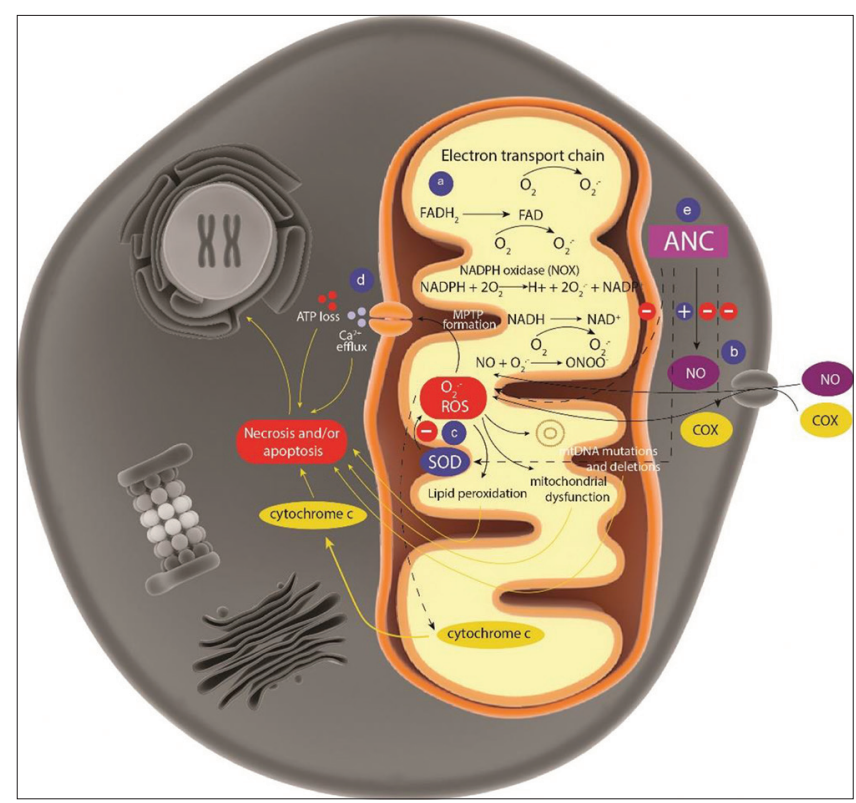

Figure 3: The generic roles of mitochondrial ROS in cell death (a) mitochondrial electron transport chain and a series of chemical reaction to generate ATP lead to ROS (O2-) accumulation. (b) In addition, external environment can become another source of free radicals, such as the involvement of COX and NO, with the latter being associated with the production of peroxynitrite. (c) Free radicals (mostly ROS) in the presence of imbalance endogenous antioxidant enzymes (primarily SOD), will induce oxidative stress, all of which injures cell and causes cellular death through various mechanisms, including mitochondrial DNA (mtDNA) mutations and deletions with subsequent mitochondrial dysfunction, lipid peroxidation, and release of cytochrome $c$ to the cytoplasm. (d) ROS also induces mitochondrial permeability transition pore formation, an opening in the mitochondrial outer membrane facilitating the efflux of calcium ions and ATP into the cytoplasm, leading to cellular death. (e) ANC directly suppresses ROS production from various sources, as well as inhibits other molecules with pro-ROS formation such as NO and COX. It also boosts endogenous antioxidant levels (e.g., SOD and GSH) to neutralize ROS. All of them ultimately result in reduced oxidative stress and protects cells from necrosis and/or apoptosis. (Some picture materials were taken and modified from the library of science and medical illustrations by sommersault 18:24, licensed under CC BY-NC-SA 4.0, materials are available under Public License) 
The existence of a free radical may be omitted on an individual basis, but it can be problematic when massive free radicals appear simultaneously over a prolonged period of time, which is usually found during oxidative stress. Oxidative stress can be detrimental to the cells and tissues because free radicals damage all of the cellular components (including organelles, lipids, proteins, and DNA), inducing apoptosis. This is especially relevant for neurons in the CNS in which they contain high levels of polyunsaturated fatty acids, thus is prone to cellular damage [177]. It is also important to note that mitochondrial DNA is more vulnerable to ROS than the nuclear DNA, thus mitochondrial dysfunction may result in more ROS production [178].

Even worse, oxidative stress can initiate an inflammatory cascade wherein the surrounding cells, including neurons and resident glial cells, to be activated and further produce various pro-inflammatory molecules, along with increased production of more free radicals. The activation of glial cells by means of toll-like receptors has been shown to induce the release of various pro-inflammatory cytokines and ROS at the same time [179]. On chronic activation of these glial cells, they are known to secrete more superoxide which can react to NO (which is also produced by glial cells) to generate peroxynitrite which has been shown to be detrimental to neurons [177]. Moreover, NF-KB, a protein complex responsible for the activation of glial cells, is also a strong inducer of NOX2 and inducible NO synthase/iNOS (an enzyme that catalyzes NO production), thus also responsible to the generation of ROS and subsequent cellular damage [180]. On the other hand, as previously described, NF-KB was also responsible for the upregulation of COX-2 enzyme, thus increases PGEs production, and subsequently elevates the superoxide levels as a byproduct of PGEs production, further damaging the cells [177]. This positive feedback can maintain a vicious cycle with linear increase in its magnitude with regard to inflammation and tissue damage, thus initiating, maintaining, and increasing the intensity of nociceptive stimuli.

The folie à deux actions between oxidative stress and inflammation also affect the pathophysiology of pain in various pathological states. For example, they have been linked as a culprit for diabetic neuropathy, wherein a chronic persistent hyperglycemic state induced peripheral nerve damage, increased accumulation of advanced glycation end products and activated various inflammatory pathways [181]. Another example is cancer that metastasize to bone was known to upregulate glutamate release responsible for cancer-induced bone pain and attenuation of its release could reduce the pain [182]. In addition, cancer chemotherapy has also been identified to produce oxidative stress and inflammation, further complicating cancer treatment through peripheral nerve damage and the resulting neuropathy [183]. Oxidative stress is also thought to contribute to the development of osteoarthritis by inducing telomere instability, replicative senescence, and chondrocyte impairment in the affected cartilage [184]. Furthermore, oxidative stress also triggers an inflammatory state and thus, initiating nociceptive stimulation in OA as predicted [185].

Furthermore, ROS has been shown to induce and maintain central sensitization in the spinal cord through the regulation of $\mathrm{N}$-methyl-D-aspartate and AMPARs and its downstream effect of LTP [186], [187]. ROS also activated TRPA1 and TRPV1, ion channels known to involve in membrane depolarization and consequent nociceptive sensitization in the spinal cord, in chronic pain after spinal cord injury (SCI) [72], [188], [189], [190]. Similarly, hydrogen peroxide $\left(\mathrm{H}_{2} \mathrm{O}_{2}\right)$, a product of cellular respiration, has been demonstrated to modulate synaptic plasticity and affecting the release of calcium ions in the interneurons of spinal cord dorsal horn neurons with the consequent nociceptive sensitization [188], [191], [192], [193]. Interestingly, nociceptive pain like capsaicin-induced hyperalgesia was shown to cause superoxide accumulation and concomitant reduction of antioxidant superoxide dismutase (SOD)-2 activity [194], suggesting a direct causative link between oxidative stress and antioxidant imbalance with the generation of nociceptive and neuropathic pain.

\section{The anti-oxidant properties of anthocyanin}

ANC exerts potent antioxidant activities. Its antioxidant potential depends on its chemical structure and the subsequent hydroxylation, methylation, acylation, and glycosylation patterns [195], [196], [197]. ANC has potent superoxide- and peroxynitrite-scavenging activities [198]. It, therefore, also inhibits lipid peroxidation [199]. It was reported that different ANC variants exert different magnitude of antioxidant capacities. Accordingly, ANC's antioxidant power can be ranked as follows (from strongest to weakest): Delphinidin, petunidin, malvidin (equals to cyanidin), peonidin, and pelargonidin [9], [198]. On raw foods (e.g., in vegetables, and fruits), ANCs were commonly found alongside with other compounds, such as Vitamin $\mathrm{C}$ and phenol, thus enabling them to act synergistically as antioxidants [200].

It was proposed that ANC acts through both direct and indirect mechanisms. It has a direct freeradical scavenging activity because it can donate the electron to the reactive free radicals, thus stabilizing it [9]. In fact, ANC can bind with superoxide, singlet oxygen, peroxide, hydrogen peroxide, and hydroxyl radicals [201], [202], [203], [204], [205]. Whereas indirectly, it increases in vivo endogenous antioxidant activities, such as increasing intrinsic SOD and glutathione peroxidase gene expressions and levels or reducing ROS formation through inhibiting NADPH oxidase [206], [207]. These comprehensive mechanisms ergo reduce as well as neutralize various free radicals. 
Clinically, ingestion of ANC derived from blueberries was shown to increase serum antioxidant status in human subjects [208], [209]. Likewise, administration of cyanidin 3-glucoside to rats was shown to reduce thiobarbituric acid reactive substances (TBARS) and protection against lipid peroxidation amidst no elevation of endogenous antioxidants. This study, therefore, is in accordance with the direct free-radicals scavenging mechanisms of ANC [210]. Furthermore, ethanol and water extract of purple sweet potato (PSP) had been demonstrated to suppress malondialdehyde levels in cell culture medium [211]. PSP is known for its ANC-rich content [212], whereas malondialdehyde, similar to TBARS, is the most frequently used biomarker for oxidative stress in the presence of various diseases [213].

There has been no direct study which links ANC with its potential ability to reduce free radicals in the event of inflammatory pain. However, some evidence can be used to infer several notions. First, ANC has specific neuroprotective mechanisms against antioxidants. ANC was shown to be protective against apoptosis of mitochondrial oxidative stressinduced cerebellar granule neurons through increased glutathione (GSH) levels, inhibiting lipid peroxidation and cardiolipin oxidation, and prevention of mitochondrial fragmentation [214]. Second, ANC is permeable to viable neurons. It was shown that ANC metabolites can prevent ROS formation on both the cellular membrane and cytosol of human neuronal cell line, suggesting that it can be up taken by neurons in the CNS and PNS [215]. Indeed, ANC was shown to readily penetrate blood-brain barrier [216], [217] and could be identified in the cortex, cerebellum, hippocampus, and striatum of rats fed daily with $2 \%$ blueberry for 10 weeks [218]. Third, ANC can act centrally to attenuate CNS demyelination, reduce inflammation, and scavenge free radicals. ANC can be detected in the peripheral interstitial fluid and its administration to ethidium bromide-induced pontine demyelination rat models has been shown to restore the $\mathrm{Na}^{+} / \mathrm{K}^{+}$ATPase pump activities of these cells (suggesting protection against demyelination), reduce pro-inflammatory cytokines (IL-1 $\beta$, IL-6, TNF$\alpha$, and IFN- $\gamma$ ) levels, and combat oxidative stress by increasing SOD levels [219]. Fourth, ANC can act in the PNS as it was demonstrated to promote myelination in the peripheral nerve through increase Sirt2 protein known to involve in myelination in mouse embryonic Schwann cell culture model [220].

If we take a look at these notions, it is prudent to assume that ANC could attenuate both nociceptive and neuropathic pain through its neurotrophic and neuroprotective mechanisms against direct noxious insults, free radicals, and inflammation. In fact, it is known that central as well as peripheral demyelination is associated with pain due to direct nerve injury or prolonged immobilization [221]. Thus, the fourth and fifth notion could actually serve a template model in which in vivo ANC might attenuate nociceptive and/or neuropathic pain. In fact, administration of pelargonidin, a subtype of ANC, has been proven to alleviate chemical and thermal hyperalgesia and reduce ROS formation in streptozotocin-induceddiabetic rat models [222]. The last study is technically a proof-of-concept of ANC's capability in alleviating pain.

\section{Conclusion}

Inflammation and oxidative stress precipitate and maintain of both nociceptive and neuropathic pain The mechanisms are pleiotropic, including activation of inflammatory pathways leading to increased production and secretion of various pro-inflammatory cytokines and chemokines, upregulation of nociceptive receptors and its associated transcription factors, as well as specific interaction with certain receptors and pathways, such as purinergic pathway (particularly for neuropathic pain). Oxidative stress also plays a major role in the pathophysiology of both pain types. ANC's protective effects against inflammation and oxidative stress had been described meticulously in this review and shown to exert multiple simultaneous actions against these pathological events. In fact, the proof-of-concept study had been translated into meaningful clinical impacts toward the treatment of several pathological pains. Given its excellent safety profile and the nature of its massive anti-inflammatory and anti-oxidant properties, ANC should be further investigated in more clinical settings for treating various nociceptive and/or neuropathic pain originated from multiple diseases.

A potentially useful approach would be to incorporate ANC as an adjunctive treatment along with currently accepted medication regimens and to compare it with the conventional medication alone in the setting of RCT whenever possible. The currently available data favors the promising results of such studies, and if it is proven so, the benefits would not only limited to alleviating the pain but also to ameliorate, if not accelerating recovery, against the primary disease itself.

\section{References}

1. Harden N, Cohen M. Unmet needs in the management of neuropathic pain. J Pain nd Symptom Manage. 2003;25(5):S12-7. https://doi.org/10.1016/s0885-3924(03)00065-4

PMid:12694988 
2. Volkow ND, McLellan AT. Opioid abuse in chronic pain misconceptions and mitigation strategies. N Engl J Med. 2016;374(13):1253-63. https://doi.org/10.1056/nejmra1507771 PMid:27028915

3. Johannes CB, Le TK, Zhou X, Johnston JA, Dworkin RH. The prevalence of chronic pain in United States adults: results of an Internet-based survey. J Pain. 2010;11(11):1230-9. https://doi. org/10.1016/j.jpain.2010.07.002

PMid:20797916

4. Ohnishi $\mathrm{R}$, Ito $\mathrm{H}$, Kasajima $\mathrm{N}$, Kaneda $\mathrm{M}$, Kariyama $\mathrm{R}$, Kumon $\mathrm{H}$, et al. Urinary excretion of anthocyanins in humans after cranberry juice ingestion. Biosci Biotechnol Biochem. 2006;70(7):1681-7. https://doi.org/10.1271/bbb.60023 PMid:16861803

5. Cassidy A, Mukamal KJ, Liu L, Franz M, Eliassen AH, Rimm EB. High anthocyanin intake is associated with a reduced risk of myocardial infarction in young and middle-aged women. Circulation. 2013;127(2):188-96. https://doi.org/10.1161/ circulationaha. 112.122408

PMid:23319811

6. Li S, Wu B, Fu W, Reddivari L. The anti-inflammatory effects of dietary anthocyanins against ulcerative colitis. Int J Mol Sci. 2019;20(10):2588. https://doi.org/10.3390/ijms20102588 PMid:31137777

7. Tall J, Seeram N, Zhao C, Nair M, Meyer R, Raja S. Tart cherry anthocyanins suppress inflammation-induced pain behavior in rat. Behav Brain Res. 2004;153(1):181-8. https://doi. org/10.1016/j.bbr.2003.11.011

PMid:15219719

8. Putta S, Yarla NS, Kumar KE, Lakkappa DB, Kamal MA, Scotti L, et al. Preventive and therapeutic potentials of anthocyanins in diabetes and associated complications. Curr Med Chem. 2018;25(39):5347-71. https://doi.org/10.2174/09298673256661 71206101945

PMid:29210634

9. Pojer E, Mattivi F, Johnson D, Stockley CS. The case for anthocyanin consumption to promote human health: A review. Compr Rev Food Sci Food Saf. 2013;12(5):483-508. https://doi. org/10.1111/1541-4337.12024

10. Miguel MG. Anthocyanins: Antioxidant and/or anti-inflammatory activities. J Appl Pharm Sci. 2011;1(6):7-15.

11. Prior RL, $\mathrm{Wu} X$. Anthocyanins: Structural characteristics that result in unique metabolic patterns and biological activities. Free Radic Res. 2006;40(10):1014-28. https://doi. org/10.1080/10715760600758522 PMid: 17015246

12. Cheng J, Wei G, Zhou H, Gu C, Vimolmangkang S, Liao L, et al. Unraveling the mechanism underlying the glycosylation and methylation of anthocyanins in peach. Plant Physiol. 2014;166(2):1044-58. https://doi.org/10.1104/pp.114.246876 PMid:25106821

13. Wahyuningsih $\mathrm{S}$, Wulandari $\mathrm{L}$, Wartono MW, Munawaroh $\mathrm{H}$, Ramelan $\mathrm{AH}$. The effect of $\mathrm{pH}$ and color stability of anthocyanin on food colorant. IOP Conf Ser Mater Sci Eng. 2017;193(1):12047. https://doi.org/10.1088/1757-899x/193/1/012047

14. Horbowicz M, Kosson R, Grzesiuk A, Dębski H. Anthocyanins of fruits and vegetables their occurrence, analysis and role in human nutrition. Veg Crops Res Bull 2008;68:5-22. https://doi. org/10.2478/v10032-008-0001-8

15. Lapidot T, Harel S, Akiri B, Granit R, Kanner J. PH-dependent forms of red wine anthocyanins as antioxidants. J Agric Food Chem. 1999;47(1):67-70. https://doi.org/10.1021/jf980704g PMid:10563851

16. Bowen-Forbes CS, Zhang Y, Nair MG. Anthocyanin content, antioxidant, anti-inflammatory and anticancer properties of blackberry and raspberry fruits. J Food Compos Anal. 2010;23(6):554-60. https://doi.org/10.1016/j.jfca.2009.08.012

17. Bridle P, Timberlake CF. Anthocyanins as natural food colours selected aspects. Food Chem. 1997;58(1):103-9. https://doi. org/10.1016/s0308-8146(96)00222-1

18. Prior RL, Wu X, Schaich K. Standardized methods for the determination of antioxidant capacity and phenolics in foods and dietary supplements. J Agric Food Chem. 2005;53(10):4290-302. https://doi.org/10.1021/jf0502698

PMid: 15884874

19. Ogawa K, Sakakibara H, Iwata R, Ishii T, Sato T, Goda T, et al. Anthocyanin composition and antioxidant activity of the crowberry (Empetrum nigrum) and other berries. J Agric Food Chem. 2008;56(12):4457-62. https://doi.org/10.1021/jf800406v PMid: 18522397

20. Neveu V, Perez-Jiménez J, Vos F, Crespy V, du Chaffaut L, Mennen L, et al. Phenol-explorer: An online comprehensive database on polyphenol contents in foods. Database. 2010;2010:bap024. https://doi.org/10.1093/database/bap024 PMid:20428313

21. Passamonti S, Vrhovsek U, Vanzo A, Mattivi F. The stomach as a site for anthocyanins absorption from food. FEBS Lett. 2003;544(1-3):210-3. https://doi.org/10.1016/ s0014-5793(03)00504-0 PMid: 12782318

22. Talavera S, Felgines C, Texier O, Besson C, Gil-Izquierdo A Lamaison $\mathrm{JL}$, et al. Anthocyanin metabolism in rats and their distribution to digestive area, kidney, and brain. J Agric Food Chem. 2005;53(10):3902-8. https://doi.org/10.1021/jf050145v PMid: 15884815

23. Tsuda T, Horio F, Osawa T. Absorption and metabolism of cyanidin 3-O-beta-D-glucoside in rats. FEBS Lett. 1999;449(2-3):179-82. https://doi.org/10.1016/s0014-5793(99)00407-x PMid:10338127

24. Matsumoto $\mathrm{H}$, Inaba $\mathrm{H}$, Kishi $\mathrm{M}$, Tominaga $\mathrm{S}$, Hirayama $\mathrm{M}$ Tsuda T. Orally administered delphinidin 3-rutinoside and cyanidin 3-rutinoside are directly absorbed in rats and humans and appear in the blood as the intact forms. J Agric Food Chem. 2001;49(3):1546-51. https://doi.org/10.1021/jf001246q PMid:11312894

25. He J, Magnuson BA, Giusti MM. Analysis of anthocyanins in rat intestinal contents--impact of anthocyanin chemical structure on fecal excretion. J Agric Food Chem. 2005;53(8):2859-66. https://doi.org/10.1021/jf0479923

PMid: 15826031

26. Crozier A, Jaganath IB, Clifford MN. Dietary phenolics: Chemistry, bioavailability and effects on health. Nat Prod Rep. 2009;26(8):1001-43. https://doi.org/10.1039/b802662a PMid:19636448

27. Del Bo C, Ciappellano S, Klimis-Zacas D, Martini D, Gardana C Riso $\mathrm{P}$, et al. Anthocyanin absorption, metabolism, and distribution from a wild blueberry-enriched diet (Vaccinium angustifolium) is affected by diet duration in the SpragueDawley rat. J Agric Food Chem. 2010;58(4):2491-7. https://doi. org/10.1021/jf903472x

PMid:20030330

28. Kay CD, Mazza GJ, Holub BJ. Anthocyanins exist in the circulation primarily as metabolites in adult men. J Nutr. 2005;135(11):2582-8. https://doi.org/10.1093/jn/135.11.2582 PMid: 16251615

29. Mullen W, Edwards CA, Serafini M, Crozier A. Bioavailability of pelargonidin-3-O-glucoside and its metabolites in humans following the ingestion of strawberries with and without cream. J Agric Food Chem. 2008;56(3):713-9. https://doi.org/10.1021/ jf072000p 


\section{PMid:18211024}

30. Garcia-Alonso M, Minihane AM, Rimbach G, Rivas-Gonzalo JC de Pascual-Teresa S. Red wine anthocyanins are rapidly absorbed in humans and affect monocyte chemoattractant protein 1 levels and antioxidant capacity of plasma. J Nutr Biochem. 2009;20(7):521-9. https://doi.org/10.1016/j. jnutbio.2008.05.011

PMid:18789665

31. Wu X, Pittman HE $3^{\text {rd }}$, Prior RL. Pelargonidin is absorbed and metabolized differently than cyanidin after marionberry consumption in pigs. J Nutr. 2004;134(10):2603-10. https://doi. org/10.1093/jn/134.10.2603

\section{PMid: 15465754}

32. Tian Q, Giusti MM, Stoner GD, Schwartz SJ. Urinary excretion of black raspberry (Rubus occidentalis) anthocyanins and their metabolites. J Agric Food Chem. 2006;54(4):1467-72. https:// doi.org/10.1021/jf052367z

PMid: 16478275

33. Wu X, Pittman HE $3^{\text {rd }}$, McKay S, Prior RL. Aglycones and sugar moieties alter anthocyanin absorption and metabolism after berry consumption in weanling pigs. J Nutr. 2005;135(10):2417-24. https://doi.org/10.1093/jn/135.10.2417

PMid:16177206

34. Fang J. Bioavailability of anthocyanins. Drug Metab Rev. 2014;46(4):508-20

PMid:25347327

35. Kurilich AC, Clevidence BA, Britz SJ, Simon PW, Novotny JA Plasma and urine responses are lower for acylated vs nonacylated anthocyanins from raw and cooked purple carrots. J Agric Food Chem. 2005;53(16):6537-42. https://doi. org/10.1021/jf050570o

PMid: 16076146

36. Borges G, Roowi S, Rouanet JM, Duthie GG, Lean ME, Crozier A. The bioavailability of raspberry anthocyanins and ellagitannins in rats. Mol Nutr Food Res. 2007;51(6):714-25. https://doi.org/10.1002/mnfr.200700024 PMid: 17533654

37. Felgines C, Texier O, Besson C, Fraisse D, Lamaison JL, Remesy C. Blackberry anthocyanins are slightly bioavailable in rats. J Nutr. 2002;132(6):1249-53. https://doi.org/10.1093/ jn/132.6.1249

PMid:12042441

38. Felgines C, Talavera S, Gonthier MP, Texier O, Scalbert A, Lamaison $\mathrm{JL}$, et al. Strawberry anthocyanins are recovered in urine as glucuro and sulfoconjugates in humans. J Nutr. 2003;133(5):1296-301. https://doi.org/10.1093/jn/133.5.1296

PMid: 12730413

39. Ichiyanagi T, Shida Y, Rahman MM, Hatano Y, Konishi T. Bioavailability and tissue distribution of anthocyanins in bilberry (Vaccinium myrtillus L.) extract in rats. J Agric Food Chem. 2006;54(18):6578-87. https://doi.org/10.1021/jf0602370 PMid:16939312

40. Marczylo TH, Cooke D, Brown K, Steward WP, Gescher AJ. Pharmacokinetics and metabolism of the putative cancer chemopreventive agent cyanidin-3-glucoside in mice. Cancer Chemother Pharmacol. 2009;64(6):1261-8. https://doi. org/10.1007/s00280-009-0996-7 PMid:19363608

41. Matsumoto $H$, Ichiyanagi $T$, lida $H$, Ito $K$, Tsuda $T$, Hirayama $M$, et al. Ingested delphinidin-3-rutinoside is primarily excreted to urine as the intact form and to bile as the methylated form in rats. J Agric Food Chem. 2006;54(2):578-82. https://doi.org/10.1021/ jf052411a

PMid: 16417324
42. Lila MA, Burton-Freeman B, Grace M, Kalt W. Unraveling anthocyanin bioavailability for human health. Annu Rev Food Sci Technol. 2016;7:375-93. https://doi.org/10.1146/ annurev-food-041715-033346 PMid:26772410

43. Felgines $\mathrm{C}$, Krisa $\mathrm{S}$, Mauray $\mathrm{A}$, Besson $\mathrm{C}$, Lamaison JL, Scalbert A, et al. Radiolabelled cyanidin 3-O-glucoside is poorly absorbed in the mouse. $\mathrm{Br} \mathrm{J}$ Nutr. 2010;103(12):1738-45. https://doi.org/10.1017/s0007114510000061 PMid:20187984

44. Fang J. Some anthocyanins could be efficiently absorbed across the gastrointestinal mucosa: Extensive presystemic metabolism reduces apparent bioavailability. J Agric Food Chem. 2014;62(18):3904-11. https://doi.org/10.1021/jf405356b PMid:24650097

45. Kamonpatana K, Giusti MM, Chitchumroonchokchai C MorenoCruz M, Riedl KM, Kumar $P$, et al. Susceptibility of anthocyanins to ex vivo degradation in human saliva. Food Chem. 2012;135(2):738-47. https://doi.org/10.1016/j. foodchem.2012.04.110

PMid:22868153

46. Mallery SR, Budendorf DE, Larsen MP, Pei P, Tong M, Holpuch AS, et al. Effects of human oral mucosal tissue, saliva, and oral microflora on intraoral metabolism and bioactivation of black raspberry anthocyanins. Cancer Prev Res (Phila). 2011;4(8):120921. https://doi.org/10.1158/1940-6207.capr-11-0040 PMid:21558412

47. Milbury PE, Cao G, Prior RL, Blumberg J. Bioavailablility of elderberry anthocyanins. Mech Ageing Dev. 2002;123(8):9971006. https://doi.org/10.1016/s0047-6374(01)00383-9 PMid:12044949

48. Passamonti S, Vrhovsek $U$, Mattivi F. The interaction of anthocyanins with bilitranslocase. Biochem Biophys Res Commun. 2002;296(3):631-6. https://doi.org/10.1016/ s0006-291x(02)00927-0

PMid:12176028

49. Passamonti S, Terdoslavich M, Franca R, Vanzo A, Tramer F, Braidot $\mathrm{E}$, et al. Bioavailability of flavonoids: A review of their membrane transport and the function of bilitranslocase in animal and plant organisms. Curr Drug Metab. 2009;10(4):369-94. https://doi.org/10.2174/138920009788498950 PMid:19519345

50. Passamonti S, Vanzo A, Vrhovsek U, Terdoslavich M, Cocolo A Decorti G, et al. Hepatic uptake of grape anthocyanins and the role of bilitranslocase. Food Res Int. 2005;38(8):953-60. https:// doi.org/10.1016/j.foodres.2005.02.015

51. Talavera S, Felgines C, Texier O, Besson C, Lamaison JL, Remesy C. Anthocyanins are efficiently absorbed from the stomach in anesthetized rats. J Nutr. 2003;133(12):4178-82. https://doi.org/10.1093/jn/133.12.4178 PMid: 14652368

52. Fernandes I, Faria A, Calhau C, de Freitas V, Mateus N Bioavailability of anthocyanins and derivatives. J Funct Foods. 2014;7:54-66. https://doi.org/10.1016/j.jff.2013.05.010

53. Matuschek MC, Hendriks WH, McGhie TK, Reynolds GW. The jejunum is the main site of absorption for anthocyanins in mice. J Nutr Biochem. 2006;17(1):31-6.

PMid:16098729

54. He J, Wallace TC, Keatley KE, Failla ML, Giusti MM. Stability of black raspberry anthocyanins in the digestive tract lumen and transport efficiency into gastric and small intestinal tissues in the rat. J Agric Food Chem. 2009;57(8):3141-8. https://doi. org/10.1021/jf900567t PMid: 19317488

55. Hollman PC. Absorption, bioavailability, and metabolism of 
flavonoids. Pharm Biol. 2004;42(Suppl 1):74-83. https://doi. org/10.3109/13880200490893492

56. Arts IC, Sesink AL, Faassen-Peters M, Hollman PC. The type of sugar moiety is a major determinant of the small intestinal uptake and subsequent biliary excretion of dietary quercetin glycosides. Br J Nutr. 2004;91(6):841-7. https://doi.org/10.1079/ bjn20041123

PMid: 15182387

57. Manach C, Williamson G, Morand C, Scalbert A, Remesy C. Bioavailability and bioefficacy of polyphenols in humans. I. Review of 97 bioavailability studies. Am J Clin Nutr. 2005;81(Suppl 1):230S-42. https://doi.org/10.1093/ajcn/81.1.230s PMid:15640486

58. Kay CD. Aspects of anthocyanin absorption, metabolism and pharmacokinetics in humans. Nutr Res Rev. 2006;19(1):137-46. https://doi.org/10.1079/nrr2005116

PMid:19079881

59. Ichiyanagi T, Shida $Y$, Rahman MM, Hatano $Y$, Konishi T. Extended glucuronidation is another major path of cyanidin 3-O-beta-D-glucopyranoside metabolism in rats. J Agric Food Chem. 2005;53(18):7312-9. https://doi.org/10.1021/jf051002b PMid:16131148

60. Zimman A, Waterhouse AL. Enzymatic synthesis of [3'-O-methyl-(3)H]malvidin-3-glucoside from petunidin-3glucoside. J Agric Food Chem. 2002;50(8):2429-31. https://doi. org/10.1021/jf0110755

PMid:11929308

61. Vanzo A, Terdoslavich M, Brandoni A, Torres AM, Vrhovsek U, Passamonti S. Uptake of grape anthocyanins into the rat kidney and the involvement of bilitranslocase. Mol Nutr Food Res. 2008;52(10):1106-16. https://doi.org/10.1002/mnfr.200700505 PMid:18655007

62. Breinholt VM, Offord EA, Brouwer C, Nielsen SE, Brosen K, Friedberg T. In vitro investigation of cytochrome P450mediated metabolism of dietary flavonoids. Food Chem Toxicol. 2002;40(5):609-16. https://doi.org/10.1016/ s0278-6915(01)00125-9 PMid:11955666

63. Wu X, Cao G, Prior RL. Absorption and metabolism of anthocyanins in elderly women after consumption of elderberry or blueberry. J Nutr. 2002;132(7):1865-71. https://doi. org/10.1093/jn/132.7.1865

PMid:12097661

64. Yeo M, Na YM, Kim DK, Kim YB, Wang HJ, Lee JA, et al. The loss of phenol sulfotransferase 1 in hepatocellular carcinogenesis. Proteomics. 2010;10(2):266-76. https://doi.org/10.1002/ pmic.200900721

65. Butler PR, Anderson RJ, Venton DL. Human platelet phenol sulfotransferase: Partial purification and detection of two forms of the enzyme. J Neurochem. 1983;41(3):630-9. https://doi. org/10.1111/j.1471-4159.1983.tb04788.x

66. Felgines C, Talavera S, Texier O, Gil-Izquierdo A, Lamaison JL, Remesy C. Blackberry anthocyanins are mainly recovered from urine as methylated and glucuronidated conjugates in humans. J Agric Food Chem. 2005;53(20):7721-7. https://doi. org/10.1021/jf051092k

PMid:16190623

67. Kalt W, Liu Y, McDonald JE, Vinqvist-Tymchuk MR, Fillmore SA. Anthocyanin metabolites are abundant and persistent in human urine. J Agric Food Chem. 2014;62(18):3926-34. https://doi. org/10.1021/j5500107j

PMid:24432743

68. Czank C, Cassidy A, Zhang Q, Morrison DJ, Preston T, Kroon PA, et al. Human metabolism and elimination of the anthocyanin, cyanidin-3-glucoside: A (13)C-tracer study. Am J Clin Nutr.
2013;97(5):995-1003. https://doi.org/10.3945/ajcn.112.049247 PMid:23604435

69. Kalt W, McDonald JE, Liu Y, Fillmore SA. Flavonoid metabolites in human urine during blueberry anthocyanin intake. J Agric Food Chem. 2017;65(8):1582-91. https://doi.org/10.1021/acs. jafc. 6 b05455

PMid:28150498

70. Sakakibara H, Ogawa T, Koyanagi A, Kobayashi S, Goda T, Kumazawa $\mathrm{S}$, et al. Distribution and excretion of bilberry anthocyanins [corrected] in mice. J Agric Food Chem. 2009;57(17):7681-6. https://doi.org/10.1021/jf901341b PMid:19663426

71. Merskey H. IASP Task Force on Taxonomy Australia Classification of Chronic Pain. Seattle: IASP Press; 1994.

72. Gold MS, Gebhart GF. Nociceptor sensitization in pain pathogenesis. Nat Med. 2010;16(11):1248-57. https://doi. org/10.1038/nm.2235

PMid:20948530

73. Anwar K. Pathophysiology of pain. Dis Mon. 2016;62(9):324-9. PMid:27329514

74. Zhang JM, An J. Cytokines, inflammation, and pain. Int Anesthesiol Clin. 2007;45(2):27-37.

PMid:17426506

75. Stammers AT, Liu J, Kwon BK. Expression of inflammatory cytokines following acute spinal cord injury in a rodent model. J Neurosci Res. 2012;90(4):782-90. https://doi.org/10.1002/ jnr.22820 PMid:22420033

76. Siemionow K, Klimczak A, Brzezicki G, Siemionow M, McLain RF. The effects of inflammation on glial fibrillary acidic protein expression in satellite cells of the dorsal root ganglion. Spine (Phila Pa 1976). 2009;34(16):1631-7. https://doi. org/10.1097/brs.0b013e3181ab1f68 PMid:19770604

77. Dawes JM, Antunes-Martins A, Perkins JR, Paterson KJ, Sisignano M, Schmid R, et al. Genome-wide transcriptional profiling of skin and dorsal root ganglia after ultraviolet-Binduced inflammation. PLoS One. 2014;9(4):e93338. https://doi. org/10.1371/journal.pone.0093338

PMid:24732968

78. Karthikeyan A, Patnala R, Jadhav SP, Eng-Ang L, Dheen ST. MicroRNAs: Key players in microglia and astrocyte mediated inflammation in CNS pathologies. Curr Med Chem. 2016;23(30):3528-46. https://doi.org/10.2174/09298673236661 60814001040

PMid:27528056

79. Nakano N, Nishiyama C, Yagita H, Hara M, Motomura Y, Kubo M, Okumura $\mathrm{K}$, et al. Notch signaling enhances FcepsilonRImediated cytokine production by mast cells through direct and indirect mechanisms. J Immunol. 2015;194(9):4535-44. https:// doi.org/10.4049/jimmunol.1301850

PMid:25821223

80. Stepanova OI, Safronova NU, Furaeva KN, Lvova TU, Sokolov DI, Selkov SA. Effects of placental secretory factors on cytokine production by endothelial cells. Bull Exp Biol Med. 2013;154(3):375-8. https://doi.org/10.1007/s10517-013-1954-2 PMid:23484204

81. Qin Y, Hua M, Duan Y, Gao Y, Shao X, Wang H, et al. TNF-alpha expression in Schwann cells is induced by LPS and NF-kappaBdependent pathways. Neurochem Res. 2012;37(4):722-31. https://doi.org/10.1007/s11064-011-0664-2 PMid:22219126

82. Hasegawa S, Kohro Y, Shiratori M, Ishii S, Shimizu T, Tsuda M, et al. Role of PAF receptor in proinflammatory cytokine 
expression in the dorsal root ganglion and tactile allodynia in a rodent model of neuropathic pain. PLoS One. 2010;5(5):e10467. https://doi.org/10.1371/journal.pone.0010467

83. Watkins LR, Wiertelak EP, Goehler LE, Smith KP Martin D, Maier SF. Characterization of cytokine-induced hyperalgesia. Brain Res. 1994;654(1):15-26. https://doi. org/10.1016/0006-8993(94)91566-0

PMid:7982088

84. Wang KC, Wang SJ, Fan LW, Cai Z, Rhodes PG, Tien LT. Interleukin-1 receptor antagonist ameliorates neonatal lipopolysaccharide-induced long-lasting hyperalgesia in the adult rats. Toxicology. 2011;279(1-3):123-9. https://doi. org/10.1016/j.tox.2010.10.002

PMid:20937348

85. Sweitzer S, Martin D, DeLeo JA. Intrathecal interleukin-1 receptor antagonist in combination with soluble tumor necrosis factor receptor exhibits an anti-allodynic action in a rat model of neuropathic pain. Neuroscience. 2001;103(2):529-39. https:// doi.org/10.1016/s0306-4522(00)00574-1

PMid:11246166

86. Katsuura G, Gottschall PE, DahI RR, ArimuraA. Interleukin-1 beta increases prostaglandin E2 in rat astrocyte cultures: Modulatory effect of neuropeptides. Endocrinology. 1989;124(6):3125-7. https://doi.org/10.1210/endo-124-6-3125

PMid:2785913

87. Hart RP, Shadiack AM, Jonakait GM. Substance P gene expression is regulated by interleukin-1 in cultured sympathetic ganglia. J Neurosci Res. 1991;29(3):282-91. https://doi. org/10.1002/jnr.490290303

88. Leibinger M, Muller A, Gobrecht $P$, Diekmann H, Andreadaki A, Fischer D. Interleukin-6 contributes to CNS axon regeneration upon inflammatory stimulation. Cell Death Dis. 2013;4:e609. https://doi.org/10.1038/cddis.2013.126 PMid:23618907

89. Erta M, Quintana A, Hidalgo J. Interleukin-6, a major cytokine in the central nervous system. Int J Biol Sci. 2012;8(9):1254-66. https://doi.org/10.7150/ijbs.4679

PMid:23136554

90. Millan MJ. The induction of pain: An integrative review. Prog Neurobiol. 1999;57(1):1-164.

PMid:9987804

91. DeLeo JA, Colburn RW, Nichols M, Malhotra A. Interleukin6-mediated hyperalgesia/allodynia and increased spinal IL-6 expression in a rat mononeuropathy model. J Interferon Cytokine Res. 1996;16(9):695-700. https://doi.org/10.1089/ jir.1996.16.695

PMid:8887053

92. Ramer MS, Murphy PG, Richardson PM, Bisby MA. Spinal nerve lesion-induced mechanoallodynia and adrenergic sprouting in sensory ganglia are attenuated in interleukin-6 knockout mice. Pain. 1998;78(2):115-21. https://doi.org/10.1016/ s0304-3959(98)00121-3

PMid:9839821

93. Zhou YQ, Liu Z, Liu ZH, Chen SP, Li M, Shahveranov A, et al. Interleukin-6: An emerging regulator of pathological pain. $J$ Neuroinflammation. 2016;13(1):141. https://doi.org/10.1186/ s12974-016-0607-6

PMid:27267059

94. Dong Y, Mao-Ying QL, Chen JW, Yang CJ, Wang YQ, Tan ZM. Involvement of EphB1 receptor/ephrinB1 ligand in bone cancer pain. Neurosci Lett. 2011;496(3):163-7. https://doi.org/10.1016/j. neulet.2011.04.008

PMid:21514363

95. Fang D, Kong LY, Cai J, Li S, Liu XD, Han JS, et al. Interleukin6 -mediated functional upregulation of TRPV1 receptors in dorsal root ganglion neurons through the activation of JAK/PI3K signaling pathway: Roles in the development of bone cancer pain in a rat model. Pain. 2015;156(6):1124-44. https://doi. org/10.1097/j.pain.0000000000000158 PMid:25775359

96. Boka G, Anglade P, Wallach D, Javoy-Agid F, Agid Y, Hirsch EC. Immunocytochemical analysis of tumor necrosis factor and its receptorsinParkinson'sdisease.NeurosciLett.1994;172(1-2):1514. https://doi.org/10.1016/0304-3940(94)90684-x

PMid:8084523

97. Sinclair SM, Shamji MF, Chen J, Jing L, Richardson WJ, Brown CR, et al. Attenuation of inflammatory events in human intervertebral disc cells with a tumor necrosis factor antagonist. Spine (Phila Pa 1976). 2011;36(15):1190-6. https://doi. org/10.1097/brs.0b013e3181ebdb43

PMid:21217452

98. Choi Jl, Svensson Cl, Koehrn FJ, Bhuskute A, Sorkin LS Peripheral inflammation induces tumor necrosis factor dependent AMPA receptor trafficking and Akt phosphorylation in spinal cord in addition to pain behavior. Pain. 2010;149(2):243-53. https:// doi.org/10.1016/j.pain.2010.02.008

PMid:20202754

99. Deshmane SL, Kremlev S, Amini S, Sawaya BE. Monocyte chemoattractant protein-1 (MCP-1): An overview. J Interferon Cytokine Res. 2009;29(6):313-26. https://doi.org/10.1089/ jir.2008.0027

\section{PMid:19441883}

100. Samad TA, Moore KA, Sapirstein A, Billet S, Allchorne A, Poole S, et al. Interleukin-1[beta]-mediated induction of Cox-2 in the CNS contributes to inflammatory pain hypersensitivity. Nature. 2001;410(6827):471-5. https://doi.org/10.1038/35068566 PMid:11260714

101. Fu JY, Masferrer JL, Seibert K, Raz A, Needleman P. The induction and suppression of prostaglandin $\mathrm{H} 2$ synthase (cyclooxygenase) in human monocytes. J Biol Chem. 1990;265(28):16737-40

PMid:2120205

102. Murakami M, Naraba H, Tanioka T, Semmyo N, Nakatani $Y$, Kojima F, et al. Regulation of prostaglandin E2 biosynthesis by inducible membrane-associated prostaglandin E2 synthase that acts in concert with cyclooxygenase-2. J Biol Chem. 2000;275(42):32783-92. https://doi.org/10.1074/jbc. m003505200

PMid:10869354

103. Sugimoto $Y$, Narumiya S. Prostaglandin E receptors. J Bio Chem. 2007;282(16):11613-7. https://doi.org/10.1074/jbc. r600038200 PMid:17329241

104. Bhave G, Zhu W, Wang H, Brasier DJ, Oxford GS, Gereau RW. cAMP-dependent protein kinase regulates desensitization of the capsaicin receptor (VR1) by direct phosphorylation. Neuron. 2002;35(4):721-31. https://doi.org/10.1016/ s0896-6273(02)00802-4 PMid:12194871

105. Ji RR, Gereau RW, Malcangio M, Strichartz GR. MAP kinase and pain. Brain Res Rev. 2009;60(1):135-48. https://doi. org/10.1016/j.brainresrev.2008.12.011 PMid:19150373

106. Ji RR, Suter MR. p38 MAPK, microglial signaling, and neuropathic pain. Mol Pain. 2007;3:33. https://doi. org/10.1186/1744-8069-3-33 PMid: 17974036

107. Svensson $\mathrm{Cl}$, MarsalaM, WesterlundA, CalcuttNA, CampanaWM, Freshwater JD, et al. Activation of p38 mitogen-activated protein kinase in spinal microglia is a critical link in inflammation-induced 
spinal pain processing. J Neurochem. 2003;86(6):1534-44. https://doi.org/10.1046/j.1471-4159.2003.01969.x

\section{PMid:12950462}

108. Schafers M, Svensson Cl, Sommer C, Sorkin LS. Tumor necrosis factor-alpha induces mechanical allodynia after spinal nerve ligation by activation of p38 MAPK in primary sensory neurons. J Neurosci. 2003;23(7):2517-21. https://doi. org/10.1523/jneurosci.23-07-02517.2003

PMid:12684435

109. Carniglia L, Ramirez D, Durand D, Saba J, Turati J, Caruso C, et al. Neuropeptides and microglial activation in inflammation, pain, and neurodegenerative diseases. Mediators Inflamm. 2017;2017:5048616. https://doi.org/10.1155/2017/5048616

110. Coull JA, Beggs S, Boudreau D, Boivin D, Tsuda M, Inoue K, et al. BDNF from microglia causes the shift in neuronal anion gradient underlying neuropathic pain. Nature. 2005;438(7070):1017-21. https://doi.org/10.1038/nature04223

PMid: 16355225

111. Burnstock G. P2X receptors in sensory neurones. $\mathrm{Br} J$ Anaesth. 2000;84(4):476-88. PMid:10823099

112. Burnstock G. Purinergic mechanosensory transduction and visceral pain. Mol Pain. 2009;5:69. https://doi. org/10.1186/1744-8069-5-69 PMid:19948030

113. Burnstock G. Purinergic Mechanisms and Pain. Adv Pharmacol. 2016;75:91-137. PMid:26920010

114. Burnstock $G$, Kennedy $C$. Is there a basis for distinguishing two types of P2-purinoceptor? Gen Pharmacol. 1985;16(5):433-40. https://doi.org/10.1016/0306-3623(85)90001-1 PMid:2996968

115. Abbracchio MP, Burnstock G. Purinoceptors: Are there families of P2X and P2Y purinoceptors? Pharmacol Ther. 1994;64(3):44575. https://doi.org/10.1016/0163-7258(94)00048-4 PMid:7724657

116. Bornstein JC. Purinergic mechanisms in the control of gastrointestinal motility. Purinergic Signal. 2008;4(3):197-212. https://doi.org/10.1007/s11302-007-9081-z PMid: 18368521

117. Christofi FL. Purinergic receptors and gastrointestinal secretomotor function. Purinergic Signal. 2008;4(3):213-36. https://doi.org/10.1007/s11302-008-9104-4

PMid:18604596

118. Adriaensen D, Brouns I, Pintelon I, De Proost I, Timmermans JP. Evidence for a role of neuroepithelial bodies as complex airway sensors: Comparison with smooth muscle-associated airway receptors. J Appl Physiol (1985). 2006;101(3):960-70. https:// doi.org/10.1152/japplphysiol.00267.2006

PMid:16741263

119. Brouns I, De Proost I, Pintelon I, Timmermans JP, Adriaensen D. Sensory receptors in the airways: Neurochemical coding of smooth muscle-associated airway receptors and pulmonary neuroepithelial body innervation. Auton Neurosci. 2006;126127:307-19. https://doi.org/10.1016/j.autneu.2006.02.006 PMid:16600695

120. Cho T, Chaban VV. Expression of P2X3 and TRPV1 receptors in primary sensory neurons from estrogen receptors-alpha and estrogen receptor-beta knockout mice. Neuroreport. 2012;23(9):530-4. https://doi.org/10.1097/ wnr.0b013e328353fabc

PMid:22581043

121. Saloman JL, Chung MK, Ro JY. P2X(3) and TRPV1 functionally interact and mediate sensitization of trigeminal sensory neurons.
Neuroscience. 2013;232:226-38. https://doi.org/10.1016/j. neuroscience.2012.11.015

PMid:23201260

122. Burnstock G, Knight GE, Greig AV. Purinergic signaling in healthy and diseased skin. J Invest Dermatol. 2012;132(3 Pt 1):526-46. https://doi.org/10.1038/jid.2011.344

PMid:22158558

123. Hamilton SG, McMahon SB, Lewin GR. Selective activation of nociceptors by $\mathrm{P} 2 \mathrm{X}$ receptor agonists in normal and inflamed rat skin. J Physiol. 2001;534(Pt 2):437-45. https://doi. org/10.1111/j.1469-7793.2001.00437.x

PMid: 11454962

124. Xu GY, Huang LY. Peripheral inflammation sensitizes P2X receptor-mediated responses in rat dorsal root ganglion neurons. J Neurosci. 2002;22(1):93-102. https://doi.org/10.1523/ jneurosci.22-01-00093.2002

PMid:11756492

125. Yiangou $\mathrm{Y}$, Facer $\mathrm{P}$, Baecker $\mathrm{PA}$, Ford AP, Knowles $\mathrm{CH}$, Chan CL, et al. ATP-gated ion channel $P 2 X(3)$ is increased in human inflammatory bowel disease. Neurogastroenterol Motil. 2001;13(4):365-9. https://doi. org/10.1046/j.1365-2982.2001.00276.x

PMid:11576396

126. Somers GR, Hammet FM, Trute L, Southey MC, Venter DJ. Expression of the P2Y6 purinergic receptor in human $T$ cells infiltrating inflammatory bowel disease. Lab Invest. 1998;78(11):1375-83.

PMid:9840612

127. Wan P, Liu X, Xiong Y, Ren Y, Chen J, Lu N, et al. Extracellular ATP mediates inflammatory responses in colitis via P2 $x$ 7 receptor signaling. Sci Rep. 2016;6:19108. https://doi. org/10.1038/srep19108

128. Wang Y, Li G, Liang S, Zhang A, Xu C, Gao Y, et al. Role of $\mathrm{P} 2 \mathrm{X} 3$ receptor in myocardial ischemia injury and nociceptive sensory transmission. Auton Neurosci. 2008;139(1-2):30-7. https://doi.org/10.1016/j.autneu.2019.102587

PMid: 18276198

129. Thompson GW, Horackova M, Armour JA. Role of $P 1$ purinergic receptors in myocardial ischemia sensory transduction. Cardiovasc Res. 2002;53(4):888-901. https://doi.org/10.1016/ s0008-6363(01)00542-9

130. Granado M, Amor S, Montoya JJ, Monge L, Fernandez N Garcia-Villalon AL. Altered expression of P2Y2 and P2X7 purinergic receptors in the isolated rat heart mediates ischemiareperfusion injury. Vascul Pharmacol. 2015;73:96-103. https:// doi.org/10.1016/j.vph.2015.06.003

PMid:26070527

131. Watanabe T, Tsuboi Y, Sessle BJ, Iwata K, Hu JW. P2X and NMDA receptor involvement in temporomandibular joint-evoked reflex activity in rat jaw muscles. Brain Res. 2010;1346:83-91. https://doi.org/10.1016/j.brainres.2010.05.055

132. Dowd E, McQueen DS, Chessell IP, Humphrey PP. P2X receptormediated excitation of nociceptive afferents in the normal and arthritic rat knee joint. Br J Pharmacol. 1998;125(2):341-6. https://doi.org/10.1038/sj.bjp.0702080

PMid:9786507

133. Bar-Yehuda S, Rath-Wolfson L, Del Valle L, Ochaion A, Cohen S, Patoka R, et al. Induction of an antiinflammatory effect and prevention of cartilage damage in rat knee osteoarthritis by CF101 treatment. Arthritis Rheum. 2009;60(10):3061-71. https://doi.org/10.1002/art.24817

PMid:19790055

134. Martins DF, Mazzardo-Martins L, Cidral-Filho FJ, Stramosk J, Santos AR. Ankle joint mobilization affects postoperative pain through peripheral and central adenosine A1 receptors. Phys 
Ther. 2013;93(3):401-12. https://doi.org/10.2522/ptj.20120226 PMid:23086409

135. Inoue K, Tsuda M, Koizumi S. ATP receptors in pain sensation: Involvement of spinal microglia and P2X(4) receptors. Purinergic Signal. 2005;1(2):95-100. https://doi.org/10.1007/ s11302-005-6210-4 PMid: 18404495

136. Trang T, Beggs S, Salter MW. ATP receptors gate microglia signaling in neuropathic pain. Exp Neurol. 2012;234(2):354-61. https://doi.org/10.1016/j.expneurol.2011.11.012 PMid:22116040

137. Ulmann L, Hatcher JP, Hughes JP, Chaumont S, Green PJ, Conquet $\mathrm{F}$, et al. Up-regulation of $\mathrm{P} 2 \mathrm{X} 4$ receptors in spinal microglia after peripheral nerve injury mediates BDNF release and neuropathic pain. J Neurosci. 2008;28(44):11263-8. https:// doi.org/10.1523/jneurosci.2308-08.2008 PMid:18971468

138. Trang T, Beggs S, Wan X, Salter MW. P2X4-receptor-mediated synthesis and release of brain-derived neurotrophic factor in microglia is dependent on calcium and p38-mitogen-activated protein kinase activation. J Neurosci. 2009;29(11):3518-28. https://doi.org/10.1523/jneurosci.5714-08.2009 PMid:19295157

139. Gong QJ, Li YY, Xin WJ, Zang Y, Ren WJ, Wei XH, et al. ATP induces long-term potentiation of $\mathrm{C}$-fiber-evoked field potentials in spinal dorsal horn: The roles of P2X 4 receptors and p38 MAPK in microglia. Glia. 2009;57(6):583-91. https://doi.org/10.1002/ glia.20786

PMid:18837052

140. Hughes JP, Hatcher JP, Chessell IP. The role of $P 2 X(7)$ in pain and inflammation. Purinergic Signal. 2007;3(1-2):163-9. PMid:18404430

141. Ferrari D, Pizzirani C, Adinolfi E, Lemoli RM, Curti A, Idzko M, et al. The P2X7 receptor: A key player in IL-1 processing and release. J Immunol. 2006;176(7):3877-83. https://doi. org/10.4049/jimmunol.176.7.3877

PMid: 16547218

142. Chessell IP, Hatcher JP, Bountra C, Michel AD, Hughes JP, Green $\mathrm{P}$, et al. Disruption of the P2X7 purinoceptor gene abolishes chronic inflammatory and neuropathic pain. Pain. 2005;114(3):386-96. https://doi.org/10.1016/j.pain.2005.01.002 PMid: 15777864

143. Suzuki T, Hide I, Ido K, Kohsaka S, Inoue K, Nakata Y. Production and release of neuroprotective tumor necrosis factor by P2X7 receptor-activated microglia. J Neurosci. 2004;24(1):1-7. https:// doi.org/10.1523/jneurosci.3792-03.2004

PMid: 14715932

144. Shieh CH, Heinrich A, Serchov T, van Calker D, Biber K. P2X7dependent, but differentially regulated release of IL-6, CCL2, and TNF-alpha in cultured mouse microglia. Glia. 2014;62(4):592607. https://doi.org/10.1002/glia.22628 PMid:24470356

145. Li L, Wang L, Wu Z, Yao L, Wu Y, Huang L, et al. Anthocyaninrich fractions from red raspberries attenuate inflammation in both RAW264.7 macrophages and a mouse model of colitis. Sci Rep. 2014;4:6234. https://doi.org/10.1038/srep06234 PMid:25167935

146. Jeong JW, Lee WS, Shin SC, Kim GY, Choi BT, Choi YH. Anthocyanins downregulate lipopolysaccharide-induced inflammatory responses in BV2 microglial cells by suppressing the NF-kappaB and Akt/MAPKs signaling pathways. Int J Mol Sci. 2013;14(1):1502-15. https://doi.org/10.3390/ijms14011502 PMid:23344054

147. Karlsen A, RetterstøI L, Laake P, Paur I, Kjølsrud-Bøhn S,
Sandvik L, et al. Anthocyanins inhibit nuclear factor- $\mathrm{kB}$ activation in monocytes and reduce plasma concentrations of pro-inflammatory mediators in healthy adults. J Nutr. 2007;137(8):1951-4. https://doi.org/10.1093/jn/137.8.1951 PMid:17634269

148. Kim SM, Chung MJ, Ha TJ, Choi HN, Jang SJ, Kim SO, et al Neuroprotective effects of black soybean anthocyanins via inactivation of ASK1-JNK/p38 pathways and mobilization of cellular sialic acids. Life Sci. 2012;90(21-22):874-82. https://doi. org/10.1016/j.lfs.2012.04.025

PMid:22575822

149. Oak MH, Bedoui JE, Madeira SV, Chalupsky K, Schini-Kerth VB. Delphinidin and cyanidin inhibit PDGFAB-induced VEGF release in vascular smooth muscle cells by preventing activation of p38 MAPK and JNK. Br J Pharmacol. 2006;149(3):283-90. https:// doi.org/10.1038/sj.bjp.0706843

PMid: 16921400

150. Seeram NP, Momin RA, Nair MG, Bourquin LD. Cyclooxygenase inhibitory and antioxidant cyanidin glycosides in cherries and berries. Phytomedicine. 2001;8(5):362-9. https://doi. org/10.1078/0944-7113-00053 PMid:11695879

151. Mulabagal V, Lang GA, DeWitt DL, Dalavoy SS, Nair MG. Anthocyanin content, lipid peroxidation and cyclooxygenase enzyme inhibitory activities of sweet and sour cherries. J Agric Food Chem. 2009;57(4):1239-46. https://doi.org/10.1021/ jf8032039

PMid: 19199585

152. Tsoyi K, Park HB, Kim YM, Chung JI, Shin SC, Lee WS, et al. Anthocyanins from black soybean seed coats inhibit UVBinduced inflammatory cylooxygenase-2 gene expression and PGE2 production through regulation of the nuclear factorkappaB and phosphatidylinositol 3-kinase/Akt pathway. J Agric Food Chem. 2008;56(19):8969-74. https://doi.org/10.1021/ jf801345c

PMid: 18778065

153. Hwang YP, Choi JH, Yun HJ, Han EH, Kim HG, Kim JY, et al. Anthocyanins from purple sweet potato attenuate dimethylnitrosamine-induced liver injury in rats by inducing Nrf2mediated antioxidant enzymes and reducing COX-2 and iNOS expression. Food Chem Toxicol. 2011;49(1):93-9. https://doi. org/10.1016/j.fct.2010.10.002

PMid:20934476

154. Kim HJ, Xu L, Chang KC, Shin SC, Chung JI, Kang D, et al Anti-inflammatory effects of anthocyanins from black soybean seed coat on the keratinocytes and ischemia-reperfusion injury in rat skin flaps. Microsurgery. 2012;32(7):563-70. https://doi. org/10.1002/micr.22019

PMid:22821773

155. Wang D, Dubois RN. The role of COX-2 in intestinal inflammation and colorectal cancer. Oncogene. 2010;29(6):781-8. https://doi. org/10.1038/onc.2009.421 PMid:19946329

156. Sobolewski C, Cerella C, Dicato M, Ghibelli L, Diederich M. The role of cyclooxygenase-2 in cell proliferation and cell death in human malignancies. Int J Cell Biol. 2010;2010:215158. https:// doi.org/10.1155/2010/215158 PMid:20339581

157. Liu B, Qu L, Yan S. Cyclooxygenase-2 promotes tumor growth and suppresses tumor immunity. Cancer Cell Int. 2015;15(1):106. https://doi.org/10.1186/s12935-015-0260-7 PMid:26549987

158. MaW, ChabotJG, Vercauteren F, Quirion R. Injured nerve-derived COX2/PGE2 contributes to the maintenance of neuropathic pain in aged rats. Neurobiol Aging. 2010;31(7):1227-37. https:// 
doi.org/10.1016/j.neurobiolaging.2008.08.002

PMid:18786748

159. Lee Y, Rodriguez C, Dionne RA. The role of COX-2 in acute pain and the use of selective COX-2 inhibitors for acute pain relief. Curr Pharm Des. 2005;11(14):1737-55. https://doi. org/10.2174/1381612053764896

PMid:15892672

160. Sinatra R. Role of COX-2 inhibitors in the evolution of acute pain management. J Pain Symptom Manage. 2002;24(1):S18-27. https://doi.org/10.1016/s0885-3924(02)00410-4 PMid:12204484

161. Han GL, Li CM, Mazza G, Yang XG. Effect of anthocyanin rich fruit extract on PGE2 produced by endothelial cells. Wei Sheng Yan Jiu. 2005;34(5):581-4. PMid: 16329602

162. He YH, Zhou J, Wang YS, Xiao C, Tong Y, Tang JC, et al. Anti-inflammatory and anti-oxidative effects of cherries on Freund's adjuvant-induced arthritis in rats. Scand J Rheumatol. 2006;35(5):356-8. https://doi.org/10.1080/03009740600704155 PMid:17062434

163. Kim HJ, Tsoy I, Park JM, Chung JI, Shin SC, Chang KC. Anthocyanins from soybean seed coat inhibit the expression of TNF-alpha-induced genes associated with ischemia/reperfusion in endothelial cell by NF-kappaB-dependent pathway and reduce rat myocardial damages incurred by ischemia and reperfusion in vivo. FEBS Lett. 2006;580(5):1391-7. https://doi. org/10.1016/j.febslet.2006.01.062

PMid: 16457818

164. Luo H, Lv XD, Wang GE, Li YF, Kurihara H, He RR. Antiinflammatory effects of anthocyanins-rich extract from bilberry (Vaccinium myrtillus L.) on croton oil-induced ear edema and Propionibacterium acnes plus LPS-induced liver damage in mice. Int J Food Sci Nutr. 2014;65(5):594-601. https://doi.org/10 $.3109 / 09637486.2014 .886184$

\section{PMid:24548119}

165. Amin HP, Czank C, Raheem S, Zhang Q, Botting NP, Cassidy A et al. Anthocyanins and their physiologically relevant metabolites alter the expression of IL- 6 and VCAM-1 in CD40L and oxidized LDL challenged vascular endothelial cells. Mol Nutr Food Res. 2015;59(6):1095-106. https://doi.org/10.1002/mnfr.201400803

166. Farrell N, Norris G, Lee SG, Chun OK, Blesso CN. Anthocyaninrich black elderberry extract improves markers of HDL function and reduces aortic cholesterol in hyperlipidemic mice. Food Funct. 2015;6(4):1278-87. https://doi.org/10.1039/c4fo01036a PMid:25758596

167. Zhang X, Zhu Y, Song F, Yao Y, Ya F, Li D, et al. Effects of purified anthocyanin supplementation on platelet chemokines in hypocholesterolemic individuals: A randomized controlled trial. Nutr Metab. 2016;13(1):86. https://doi.org/10.1186/ s12986-016-0146-2

PMid:27933092

168. Sogo T, Terahara N, Hisanaga A, Kumamoto T, Yamashiro $T$, Wu S, et al. Anti-inflammatory activity and molecular mechanism of delphinidin 3-sambubioside, a Hibiscus anthocyanin. Biofactors. 2015;41(1):58-65. https://doi.org/10.1002/biof.1201 PMid:25728636

169. Winter AN, Ross EK, Wilkins HM, Stankiewicz TR, Wallace T, Miller $\mathrm{K}$, et al. An anthocyanin-enriched extract from strawberries delays disease onset and extends survival in the hSOD1G93A mouse model of amyotrophic lateral sclerosis. Nutr Neurosci. 2018;21:414-26. https://doi.org/10.1080/10284 15x.2017.1297023 PMid:28276271

170. Shah SA, Amin FU, Khan M, Abid MN, Rehman SU, Kim TH, et al. Anthocyanins abrogate glutamate-induced AMPK activation, oxidative stress, neuroinflammation, and neurodegeneration in postnatal rat brain. J Neuroinflammation. 2016;13(1):286. https://doi.org/10.1186/s12974-016-0752-y

PMid:27821173

171. Kuehl KS, Perrier ET, Elliot DL, Chesnutt JC. Efficacy of tart cherry juice in reducing muscle pain during running: A randomized controlled trial. J Int Soc Sports Nutr. 2010;7:17. https://doi.org/10.1186/1550-2783-7-17 PMid:20459662

172. Schumacher HR, Pullman-Mooar S, Gupta SR, Dinnella JE, Kim R, McHugh MP. Randomized double-blind crossover study of the efficacy of a tart cherry juice blend in treatment of osteoarthritis (OA) of the knee. Osteoarthritis Cartilage. 2013;21(8):1035-41. https://doi.org/10.1016/j.joca.2013.05.009 PMid:23727631

173. Tall JM, Seeram NP, Zhao C, Nair MG, Meyer RA, Raja SN. Tart cherry anthocyanins suppress inflammation-induced pain behavior in rat. Behav Brain Res. 2004;153(1):181-8. https://doi. org/10.1016/j.bbr.2003.11.011

PMid: 15219719

174. Sanchez A, Calpena AC, Clares B. Evaluating the oxidative stress in inflammation: Role of melatonin. Int $\mathrm{J}$ Mol Sci. 2015;16(8):16981-7004. https://doi.org/10.3390/ijms160816981 PMid:26225957

175. Murphy MP. How mitochondria produce reactive oxygen species. Biochem J. 2009;417(1):1-13. PMid:19061483

176. Ma MW, Wang J, Zhang Q, Wang R, Dhandapani KM, Vadlamudi RK, et al. NADPH oxidase in brain injury and neurodegenerative disorders. Mol Neurodegener. 2017;12(1):7. https://doi.org/10.1186/s13024-017-0150-7

177. Fischer R, Maier $\mathrm{O}$. Interrelation of oxidative stress and inflammation in neurodegenerative disease: Role of TNF. Oxid Med Cell Longev. 2015;2015:18. https://doi. org/10.1155/2015/610813

178. Urrutia PJ, Mena NP, Nunez MT. The interplay between iron accumulation, mitochondrial dysfunction, and inflammation during the execution step of neurodegenerative disorders. Front Pharmacol. 2014;5:38. https://doi.org/10.3389/ fphar.2014.00038

PMid:24653700

179. van Noort JM, Bsibsi M. Toll-like receptors in the CNS: Implications for neurodegeneration and repair. Prog Brain Res. 2009;175:139-48. https://doi.org/10.1016/ s0079-6123(09)17509-x

180. Morgan MJ, Liu ZG. Crosstalk of reactive oxygen species and NF-kappaB signaling. Cell Res. 2011;21(1):103-15.

PMid:21187859

181. Sandireddy R, Yerra VG, Areti A, Komirishetty P, Kumar A Neuroinflammation and oxidative stress in diabetic neuropathy: Futuristic strategies based on these targets. Int J Endocrinol. 2014;2014:674987. https://doi.org/10.1155/2014/674987 PMid:24883061

182. Ungard RG, Seidlitz EP, Singh G. Oxidative stress and cancer pain. Can J Physiol Pharmacol. 2013;91(1):31-7. https://doi. org/10.1139/cjpp-2012-0298 PMid:23368277

183. Areti A, Yerra VG, Naidu V, Kumar A. Oxidative stress and nerve damage: Role in chemotherapy induced peripheral neuropathy. Redox Biol. 2014;2:289-95. https://doi.org/10.1016/j. redox.2014.01.006 PMid:24494204

184. Yudoh K, Nguyen VT, Nakamura H, Hongo-Masuko K, Kato T, Nishioka K. Potential involvement of oxidative stress in cartilage 
senescence and development of osteoarthritis: Oxidative stress induces chondrocyte telomere instability and downregulation of chondrocyte function. Arthritis Res Ther. 2005;7(2):R380-91. https://doi.org/10.1186/ar1499

PMid:15743486

185. Ziskoven C, Jager M, Zilkens C, Bloch W, Brixius K, Krauspe R. Oxidative stress in secondary osteoarthritis: From cartilage destruction to clinical presentation? Orthop Rev (Pavia). 2010;2(2):e23. https://doi.org/10.4081/or.2010.e23 PMid:21808712

186. Lee KY, Chung K, Chung JM. Involvement of reactive oxygen species in long-term potentiation in the spinal cord dorsal horn. J Neurophysiol. 2010;103(1):382-91. https://doi.org/10.1152/ jn.90906.2008

PMid:19906875

187. Lee DZ, Chung JM, Chung K, Kang MG. Reactive oxygen species (ROS) modulate AMPA receptor phosphorylation and cell-surface localization in concert with pain-related behavior. Pain. 2012;153(9):1905-15. https://doi.org/10.1016/j. pain.2012.06.001

PMid:22770842

188. Nishio N, Taniguchi W, Sugimura YK, Takiguchi N, Yamanaka M, Kiyoyuki $\mathrm{Y}$, et al. Reactive oxygen species enhance excitatory synaptic transmission in rat spinal dorsal horn neurons by activating TRPA1 and TRPV1 channels. Neuroscience. 2013;247:201-12. https://doi.org/10.1016/j. neuroscience.2013.05.023

189. Chung MK, Jung SJ, Oh SB. Role of TRP channels in pain sensation. Adv Exp Med Biol. 2011;704:615-36.

\section{PMid:21290319}

190. Jardín I, López JJ, Diez R, Sánchez-Collado J, Cantonero C Albarrán L, et al. TRPs in pain sensation. Front Physiol. 2017;8:392. https://doi.org/10.3389/fphys.2017.00392 PMid:28649203

191. Takahashi A, Mikami M, Yang J. Hydrogen peroxide increases GABAergic mIPSC through presynaptic release of calcium from IP3 receptor-sensitive stores in spinal cord substantia gelatinosa neurons. Eur J Neurosci. 2007;25(3):705-16. https:// doi.org/10.1111/j.1460-9568.2007.05323.x

PMid:17328771

192. Roberts RA, Smith RA, Safe S, Szabo C, Tjalkens RB, Robertson FM. Toxicological and pathophysiological roles of reactive oxygen and nitrogen species. Toxicology. 2010;276(2):85-94. https://doi.org/10.1016/j.tox.2010.07.009 PMid:20643181

193. Kolberg C, Horst A, Moraes MS, Duarte FC, Riffel AP, Scheid T, et al. Peripheral oxidative stress blood markers in patients with chronic back or neck pain treated with high-velocity, low-amplitude manipulation. J Manipulative Physiol Ther. 2015;38(2):119-29. https://doi.org/10.1016/j.jmpt.2014.11.003 PMid:25487299

194. Schwartz ES, Kim HY, Wang J, Lee I, Klann E, Chung JM, et al. Persistent pain is dependent on spinal mitochondrial antioxidant levels. J Neurosci. 2009;29(1):159-68. https://doi.org/10.1523/ jneurosci.3792-08.2009

PMid:19129394

195. Kähkönen MP, Heinonen M. Antioxidant activity of anthocyanins and their aglycons. J Agric Food Chem. 2003;51(3):628-33. https://doi.org/10.1021/jf025551i

PMid:12537433

196. Rice-Evans CA, Miller NJ, Paganga G. Structure-antioxidant activity relationships of flavonoids and phenolic acids. Free Radic Biol Med. 1996;20(7):933-56. https://doi. org/10.1016/0891-5849(95)02227-9

PMid:8743980
197. Wang H, Cao G, Prior RL. Oxygen radical absorbing capacity of anthocyanins. J Agric Food Chem. 1997;45(2):304-9. https:// doi.org/10.1021/jf960421t

198. Rahman MM, Ichiyanagi T, Komiyama T, Hatano Y, Konishi T. Superoxide radical and peroxynitrite-scavenging activity of anthocyanins; structure-activity relationship and their synergism. Free Radic Res. 2006;40(9):993-1002. https://doi. org/10.1080/10715760600815322

\section{PMid:17015281}

199. Tsuda T, Shiga K, Ohshima K, Kawakishi S, Osawa T. Inhibition of lipid peroxidation and the active oxygen radical scavenging effect of anthocyanin pigments isolated from Phaseolus vulgaris L. Biochem Pharmacol. 1996;52(7):1033-9. https://doi. org/10.1016/0006-2952(96)00421-2

PMid:8831722

200. Pantelidis GE, Vasilakakis M, Manganaris GA, Diamantidis G. Antioxidant capacity, phenol, anthocyanin and ascorbic acid contents in raspberries, blackberries, red currants, gooseberries and Cornelian cherries. Food Chem. 2007;102(3):777-83. https://doi.org/10.1016/j.foodchem.2006.06.021

201. Moriyama H, Morita $Y$, Ukeda H, Sawamura M, Terahara N. Superoxide anion-scavenging activity of anthocyanin pigments. Nippon Shokuhin Kagaku Kogaku Kaishi. 2003;50(11):499-505. https://doi.org/10.3136/nskkk.50.499

202. De Rosso VV, Moran Vieyra FE, Mercadante AZ, Borsarelli CD. Singlet oxygen quenching by anthocyanin's flavylium cations. Free Radic Res. 2008;42(10):885-91. https://doi. org/10.1080/10715760802506349

PMid:18985487

203. Ichikawa $H$, Ichiyanagi $T$, Xu B, Yoshii $Y$, Nakajima $M$, Konishi T. Antioxidant activity of anthocyanin extract from purple black rice. J Med Food. 2001;4(4):211-8. https://doi. org/10.1089/10966200152744481

PMid:12639403

204. Bi X, Zhang J, Chen C, Zhang D, Li P, Ma F. Anthocyanin contributes more to hydrogen peroxide scavenging than other phenolics in apple peel. Food Chem. 2014;152:205-9. https:// doi.org/10.1016/j.foodchem.2013.11.088

PMid:24444927

205. Devi PS, Kumar MS, Das SM. DNA damage protecting activity and free radical scavenging activity of anthocyanins from red Sorghum (Sorghum bicolor) Bran. Biotechnol Res Int. 2012;2012:258787. https://doi.org/10.1155/2012/258787

206. Lim TG, Jung SK, Kim JE, Kim Y, Lee HJ, Jang TS, et al. NADPH oxidase is a novel target of delphinidin for the inhibition of UVBinduced MMP-1 expression in human dermal fibroblasts. Exp Dermatol. 2013;22(6):428-30. https://doi.org/10.1111/exd.12157 PMid:23711068

207. Xie X, Zhao R, Shen GX. Impact of cyanidin-3-glucoside on glycated LDL-induced NADPH oxidase activation, mitochondrial dysfunction and cell viability in cultured vascular endothelial cells. Int J Mol Sci. 2012;13(12):15867-80. https://doi. org/10.3390/ijms131215867

PMid:23443099

208. Mazza G, Kay CD, Cottrell T, Holub BJ. Absorption of anthocyanins from blueberries and serum antioxidant status in human subjects. J Agric Food Chem. 2002;50(26):7731-7. https://doi.org/10.1021/jf020690I

PMid:12475297

209. Kay CD, Holub BJ. The effect of wild blueberry (Vaccinium angustifolium) consumption on postprandial serum antioxidant status in human subjects. Br J Nutr. 2007;88(4):389-98. https:// doi.org/10.1079/bjn2002665

PMid:12323088

210. Tsuda T, Horio F, Osawa T. Dietary cyanidin 3-O- $\beta$-d-glucoside 
increases ex vivo oxidation resistance of serum in rats. Lipids. 1998;33(6):583-8. https://doi.org/10.1007/s11745-998-0243-5 PMid:9655373

211. Park KH, Kim JR, Lee JS, Lee H, Cho KH. Ethanol and water extract of purple sweet potato exhibits anti-atherosclerotic activity and inhibits protein glycation. J Med Food. 2010;13(1):91-8. https://doi.org/10.1089/jmf.2009.1077

PMid:20136441

212. Steed LE, Truong VD. Anthocyanin content, antioxidant activity, and selected physical properties of flowable purple-fleshed sweetpotato purees. J Food Sci. 2008;73(5):S215-21. https:// doi.org/10.1111/j.1750-3841.2008.00774.x

PMid:18577013

213. Khoubnasabjafari M, Ansarin K, Jouyban A. Reliability of malondialdehyde as a biomarker of oxidative stress in psychological disorders. Bioimpacts. 2015;5(3):123-7. https:// doi.org/10.15171/bi.2015.20

PMid:26457249

214. Kelsey N, Hulick W, Winter A, Ross E, Linseman D. Neuroprotective effects of anthocyanins on apoptosis induced by mitochondrial oxidative stress. Nutr Neurosci. 2011;14(6):24959. https://doi.org/10.1179/1476830511y.0000000020 PMid:22053756

215. Tarozzi A, Morroni F, Hrelia S, Angeloni C, Marchesi A, CantelliForti G, et al. Neuroprotective effects of anthocyanins and their in vivo metabolites in SH-SY5Y cells. Neurosci Lett. 2007;424(1):36-40. https://doi.org/10.1016/j.neulet.2007.07.017 PMid: 17709193

216. Passamonti S, Vrhovsek U, Vanzo A, Mattivi F. Fast access of some grape pigments to the brain. J Agric Food Chem. 2005;53(18):7029-34. https://doi.org/10.1021/jf050565k
PMid:16131107

217. Kalt W, Blumberg JB, McDonald JE, Vinqvist-Tymchuk MR Fillmore SA, Graf BA, et al. Identification of anthocyanins in the liver, eye, and brain of blueberry-fed pigs. J Agric Food Chem. 2008;56(3):705-12. https://doi.org/10.1021/jf071998

PMid:18211026

218. Andres-Lacueva C, Shukitt-Hale B, Galli RL, Jauregui O, Lamuela-Raventos RM, Joseph JA. Anthocyanins in aged blueberry-fed rats are found centrally and may enhance memory. Nutr Neurosci. 2005;8(2):111-20. https://doi. org/10.1080/10284150500078117

PMid: 16053243

219. Carvalho FB, Gutierres JM, Bohnert C, Zago AM, Abdalla FH, Vieira JM, et al. Anthocyanins suppress the secretion of proinflammatory mediators and oxidative stress, and restore ion pumpactivities in demyelination. J NutrBiochem. 2015;26(4):37890. https://doi.org/10.1016/j.jnutbio.2014.11.006

220. Stettner M, Wolffram K, Mausberg AK, Albrecht P, Derksen A, Methner $A$, et al. Promoting myelination in an in vitro mouse model of the peripheral nerve system: The effect of wine ingredients. PLOS One. 2013;8(6):e66079. https://doi. org/10.1371/journal.pone.0066079

PMid:23762469

221. Moulin DE. Pain in central and peripheral demyelinating disorders. Neurol Clin. 1998;16(4):889-98.

PMid:9767068

222. Mirshekar M, Roghani M, Khalili M, Baluchnejadmojarad T, Moazzen SA. Chronic oral pelargonidin alleviates streptozotocininduced diabetic neuropathic hyperalgesia in rat: Involvement of oxidative stress. Iran Biomed J. 2010;14(1-2):33-9.

PMid:20683496 